\title{
Uorden
}

\section{Controlling Emissions from Wood Burning}

Legislation and Regulations in Nordic Countries to Control Emissions from Residential Wood Burning An examination of Past Experience 

4 norden 



\section{Controlling Emissions from Wood Burning}

Legislation and Regulations in Nordic Countries to Control Emissions from Residential Wood Burning An examination of Past Experience

Thomas Levander and Svante Bodin

TemaNord 2014:517 
Controlling Emissions from Wood Burning

Legislation and Regulations in Nordic Countries to Control Emissions from Residential

Wood Burning An examination of Past Experience

Thomas Levander and Svante Bodin

ISBN 978-92-893-2742-8

http://dx.doi.org/10.6027/TN2014-517

TemaNord 2014:517

ISSN 0908-6692

(C) Nordic Council of Ministers 2014

Layout: Hanne Lebech

Cover photo: ImageSelect

This publication has been published with financial support by the Nordic Council of Ministers. However, the contents of this publication do not necessarily reflect the views, policies or recommendations of the Nordic Council of Ministers.

www.norden.org/en/publications

\section{Nordic co-operation}

Nordic co-operation is one of the world's most extensive forms of regional collaboration, involving Denmark, Finland, Iceland, Norway, Sweden, and the Faroe Islands, Greenland, and Åland.

Nordic co-operation has firm traditions in politics, the economy, and culture. It plays an important role in European and international collaboration, and aims at creating a strong Nordic community in a strong Europe.

Nordic co-operation seeks to safeguard Nordic and regional interests and principles in the global community. Common Nordic values help the region solidify its position as one of the world's most innovative and competitive.

\section{Nordic Council of Ministers}

Ved Stranden 18

DK-1061 Copenhagen K

Phone (+45) 33960200

www.norden.org 


\section{Content}

Preface

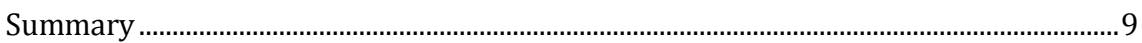

1. Introduction......................................................................................................... 13

2. Trends in Residential Wood Consumption and Emissions of Particulate

Matter in the Nordic Countries ................................................................................... 15

2.1 Wood burning Use and Trends .......................................................................... 15

2.2 Emissions of Particulate Matter ....................................................................... 20

2.3 New technology reduces emissions............................................................... 21

3. Responses to Wood Burning Emissions in the Nordic Countries.............................. 23

3.1 Historical Background ..................................................................................... 23

3.2 Current National Regulations on Emissions from Stoves and
Boilers in Nordic Countries............................................................................ 24

3.3 Incentive Programs for Improving the Environmental Impact of

Stoves and Boilers ................................................................................................. 27

3.4 Information Campaigns....................................................................................... 31

3.5 Environmental Legislation Supporting Reductions of Residential

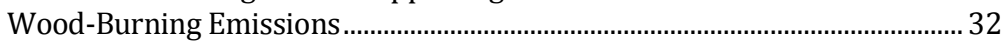

3.6 Voluntary Eco-labelling: The Nordic Swan....................................................... 37

4. International and Other Initiatives to Reduce Emissions ..............................................39

4.1 The Ecodesign Directive (2009/125/EC)......................................................... 39

4.2 The Convention on Long-Range Transboundary Air Pollution

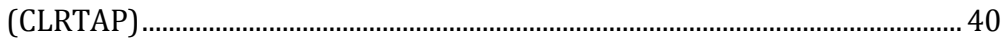

4.3 The Arctic Council ........................................................................................... 40

5. Assessing the Impact of Policies and Measures .......................................................... 43

5.1 Impact on Emissions ...................................................................................... 43

5.2 Impact of Scrapping Payments and Replacement Subsidies ........................ 44

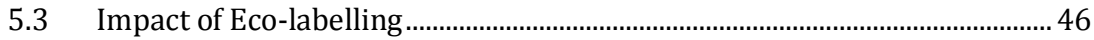

5.4 Manufacturer Responses .................................................................................... 46

6. General Assessment of Selected Policy Instruments .................................................. 49

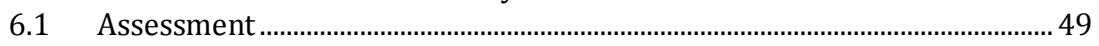

6.2 Relevance to Future Black Carbon Measures ................................................... 52

7. Conclusions and Recommendations for Future Work ............................................. 55

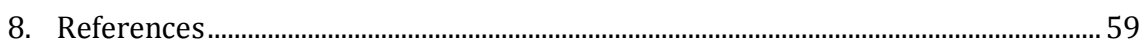

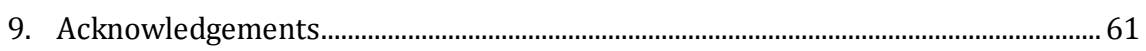

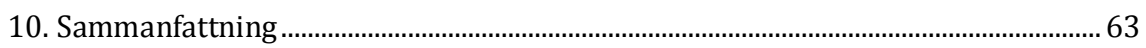

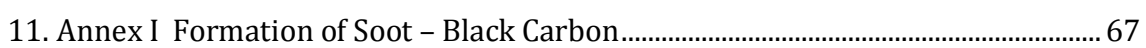

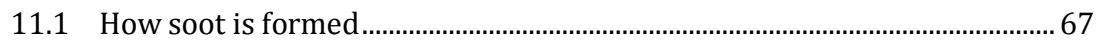

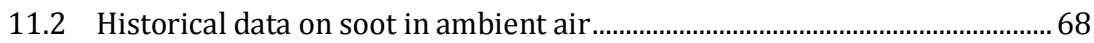

12. Annex II Wood burning Technologies on the Nordic Market ................................. 71

12.1 Basic Combustion Technologies............................................................................ 71

12.2 Wood burning stoves and boilers on the Nordic Market ................................ 73 



\section{Preface}

This report has been produced by the International Cryosphere Climate Initiative (ICCI) under a grant from the Nordic Council of Ministers under its Arctic Cooperation Program, as part of a pilot project to reduce emissions of black carbon reaching the Arctic from residential heating from wood burning in Nordic countries. Studies by the Arctic Council; the United Nations Environment Programme (UNEP); and most recently, ICCI together with the World Bank have identified this source as one of the most important impacting the Arctic, and one of the few that is growing. Because of the strong impact of black carbon on snow and ice melt, reducing its emissions from wood burning represents an important means for Nordic nations to slow Arctic warming and melting, and related impacts on the global climate system, by taking actions within our own borders.

This project also includes information campaigns in Nordic countries, to better inform those households who burn wood for residential heating on how they can "burn right" in order to minimize black carbon emissions, while at the same time reducing other pollutants harmful to human health, and increasing heating efficiency from each load of wood. The project also is working to develop a new Nordic testing protocol for measuring emissions of black carbon from stoves and small boilers, a necessary prerequisite to helping producers, consumers and governments identify the best-performing stoves in terms of low black carbon emissions, and how to make them even better. Eventually, this may lead to consumer labeling of stoves and boilers to identify low-black carbon models, and guide Nordic governments in the introduction of emission limits for residential heating from wood.

ICCI has had numerous contacts with producers, researchers and national authorities that have contributed to this report. Most of the material used in the report arose from open sources in Nordic countries, or through direct contacts with agencies, producers and scientists. In parallel to the drafting of this report, ICCI convened two workshops that also provided useful information and feedback. These included one general discussion with experts, producers and government agencies; and one technical meeting regarding testing and measurement techniques for black carbon. 
ICCI would like to express its gratitude to all those who have contributed to this report and in particular to Thomas Levander, formerly with the Swedish Energy Agency, who was responsible for all background research and pulling the extensive content of this report together.

The views expressed in this report are solely those of ICCI when not stated otherwise. 


\section{Summary}

Black carbon (the blackening component of soot) has long been recognized as a source of ambient air pollution with negative health effects, but only in recent years have scientists become aware of its role in accelerating near-term climate change. Black carbon ${ }^{1}(\mathrm{BC})$ - a form of particulate matter (PM) produced through the incomplete combustion of biomass and fossil fuels - warms the earth by absorbing heat in the atmosphere and by reducing the earth's albedo (the ability to reflect sunlight) in snow and ice covered areas. Studies have shown that BC emissions have a particularly strong impact in the Arctic, where soot particles, deposited onto snow and ice, hasten the onset of the spring melt and enhance the melting during the melt season. As ocean and land surfaces become exposed, they absorb more solar radiation, reinforcing the heating effect.

Because black carbon resides in the atmosphere for only several days to a few weeks, substantial reductions in BC emissions (especially from northern latitude countries) could significantly slow the rate of global warming over the next few decades, while yielding important health benefits. The Nordic countries, along with Russia, Canada and the United States contribute a major portion of the soot that reaches the Arctic, and hence mitigation efforts in these places are likely to have the greatest near-term positive impact on the Arctic climate. In the Nordic countries, smoke from residential wood-burning constitutes the largest source of total $\mathrm{BC}$ emissions, exceeding BC from transportation sources. It is also the only source showing a likely upward trend in the next decade if unmitigated.

This report reviews legislation and other measures in the Nordic countries pertinent to the reduction of particulate matter (PM2.5) and Black Carbon (BC) -soot. It then assesses the effectiveness of the different policy instruments used in the Nordic countries as well as points to measures which may be most effective in reducing emissions of Black Carbon and PM2.5 from wood burning.

\footnotetext{
${ }^{1}$ Black Carbon (BC) is referred to as light-absorbing refractory carbonaceous matter in this study. BC is not exactly equivalent to soot even if soot is to large extent overlapping with the definition of BC. BC particles are smaller than 1 micrometer and often around 0.1 micrometer. For a more comprehensive discussion se Annex I.
} 
The report's findings, conclusions and recommendations can be summarized as follows.

\section{I}

Regulation under the Ecodesign Directive will play a very important role for the development of better stoves and boilers over the next decade.

Current technical regulations and emission limit values in the Nordic countries to limit emissions from stoves or boilers are obsolete, and do not give incentives for manufacturers to further reduce emissions; nor do they cover black carbon. Manufactures that act on a global market often design their products to meet the most stringent standards adopted. The forthcoming regulation on emission limits for stoves and boilers under the EU Ecodesign directive will be an important tool to reduce emissions from stoves and boilers.

In order to achieve maximum benefit emissions of black carbon must also be explicitly covered by the Ecodesign directive. This goes hand in hand with the need to establish a reliable and effective testing protocol for both PM2.5 and black carbon.

\section{II}

The Nordic countries have the regulatory tools necessary to intervene in cases where wood burning results in poor air quality in individual cases, but their application varies and these measures have little effect on the regional emission reductions.

All countries have environment legislation that allows local authorities to intervene against local impacts of wood burning. In many cases, advice and guidelines are given to consumers by local authorities. Action may in theory also be taken by an Environment Court. However, it is difficult to see how these measures can contribute effectively to an overall reduction of black carbon emissions.

III

Nordic Eco-label can prove a powerful driver in Nordic countries to product development and consumer recognition related to black carbon.

Given its high recognition factor and ability to push requirements beyond the Ecodesign Directive and to reward best practices, the Nordic Swan can serve as a leading edge in the development of new testing requirements for black carbon, design of new stoves and future legal requirements. Development of joint protocols for testing emissions is a prerequisite to the development of such standards. 
IV

While subsidies may have accelerated some change-outs in local municipalities, their overall impact in comparison with municipalities without subsidies has not been studied. It is therefore difficult to calculate whether any additional air quality benefit from subsidies has occurred. Subsidies on a national scale such as a black carbon reduction intervention would certainly prove expensive, so must be considered primarily as a tool to speed development and adoption of more innovative designs.

Introducing subsidies for products that are already commercially available in the markets is rarely cost effective. Instead, there is a risk that the funds go to households that had already planned to replace their boiler. Subsidies for new and better technology are preferable but there is also a risk that subsidies distort markets.

$\mathbf{V}$

It is technically possible to accelerate the development of stoves and boilers so that emissions of both black carbon and PM2.5 can be pushed down, and the user's skill to burn a fire plays a minor role.

It is possible to develop the technology for both higher efficiency and reduced emissions. Further development of the burner heads in wood pellets boiler and stoves, refined fuel delivery systems and improved combustion chamber designs are possible technological advances. By using advanced control techniques together with inexpensive sensor technology emissions could be further reduced.

VI

There are significant uncertainties in emission factors for both $P M$ and $B C$, which also is reflected in comparative data from the Nordic countries.

In spite of the fact that stoves and boilers sold in the Nordic countries are often of the same brand, the way emission are measured and reported vary between countries, as do emission factors used to estimate the amount of emissions of particulate matter.

It is important to recognize that testing protocols should be compatible across the transport sector, industry sector and the residential sector in order to assess emission factors that reflects real-life emissions and to determine their relative contributions to the overall emissions of BC. The Nordic Countries have the opportunity however to influence the development of harmonized testing protocols for measuring emissions of $\mathrm{BC}$ and $\mathrm{PM} 2.5$. This is particularly important regarding the application of the Ecodesign Directive to domestic heating appliances. 
Effective policy interventions possible and further cooperation needed to develop a long-term strategy.

Technology development should be further promoted. It should not rely entirely on research and development, but other forms of stimulus are needed to bring new products to market. Industry and market actors have a key role in developing and putting new technology on the market.

Additional measures should be considered if the natural change out of older equipment is not expected to be sufficient to achieve the desired goal. This could for example be done by setting deadlines for using particular kinds or models of stoves. Other ways of promoting the introduction of new and better products would be by using differentiated taxes and other economic instruments.

In conclusion it would be possible to develop legislation and regulations addressing black carbon and PM2.5 for the dual purpose of reducing black carbon emissions reaching the Arctic and Black Carbon/PM2.5 causing local health problems. There is scope for further work for under the auspices of the Nordic Council of Ministers, nationally, and in other international forums. The current work on the implementation of the Ecodesign directive is especially important to the Nordic Countries, as is the next revision of the Swan mark for wood stoves and boilers anticipated for 2015. In order to reach the political goals set up by the Nordic countries such broader efforts should be initiated quite rapidly. 


\section{Introduction}

Black carbon (commonly known as soot) has long been recognized as a source of ambient air pollution with negative health effects, but only in recent years have scientists become aware of its role in accelerating near-term climate change. Black carbon (BC) - a form of particulate matter (PM) produced through the incomplete combustion of biomass and fossil fuels - warms the earth by absorbing heat in the atmosphere and by reducing the earth's albedo (the ability to reflect sunlight) in snow and ice covered areas. Studies have shown (UNEP and WMO 2011, AMAP 2011, US-EPA 2012) that BC emissions have a particularly strong impact in the Arctic, where soot particles, deposited onto snow and ice, hasten the onset of the spring melt and enhance the melting during the melt season. As ocean and land surfaces become exposed, they absorb more solar radiation, reinforcing the heating effect.

Because black carbon resides in the atmosphere for only several days to a few weeks, substantial reductions in BC emissions (especially from northern latitude countries) could significantly slow the rate of global warming over the next few decades, while yielding important health benefits. The Nordic countries, along with Russia, Canada and the United States contribute a major portion of the soot that reaches the Arctic, and hence mitigation efforts in these places are likely to have the greatest near-term positive impact on the Arctic climate. The Arctic Council has identified the major sources of black carbon emissions impacting the Arctic as diesel vehicle exhaust, open burning (both field and forest fires), residential cooking and heating, and oil and gas flaring. In the Nordic countries, smoke from residential wood-burning constitutes the largest source of total $\mathrm{BC}$ emissions, exceeding $\mathrm{BC}$ from transportation sources. It is also the only source showing a likely upward trend in the next decade if unmitigated.

Wood burning stoves and fireplaces, as well as boilers, have long played a central role in home heating in Nordic countries. Rising oil prices, combined with climate change policies aimed at promoting renewable energy over fossil fuels, will contribute to greater use of bio-fuels, especially wood, for domestic purposes. A study (Norden and IEA 2013) concluded that even in the absence of a global climate change agreement, bio-fuels in the residential sector will increase. Hence there is an 
urgent need to design and implement an effective approach to limiting black carbon emissions from these sources.

The Nordic Council of Ministers has engaged the International Cryosphere Climate Initiative (ICCI) to develop early actions to decrease black carbon emissions from wood burning in Nordic countries. The ICCI will work with governments, Nordic NGOs, technical experts and stove manufacturers to design means to effectively measure and control black carbon emissions in the residential sector.

This report provides an account of policy efforts made thus far in the Nordic countries to limit emissions from wood burning, thus far only for air quality rather than regional climate purposes. In addition, Annex I includes a description of different types of stoves ${ }^{2}$ as well a technical explanation of how the combustion process generates black carbon and other pollutants. The discussion provides an assessment of how various policies and measures previously attempted, or currently in place have affected particle emissions, as a proxy for potential future emissions aimed specifically at black carbon. Such measures include not only direct regulation, but consumer product information incentives to switch to cleaner-burning stoves, voluntary standards (such as the Nordic Swan label) and consumer information campaigns on how to use stoves more effectively. This report will consider how these previous efforts may inform and guide the broader goal of curbing black carbon emissions for the protection of the Arctic and global climate - and where these measures fall short.

\footnotetext{
${ }^{2}$ For the purposes of this study, "woodstove" refers generally to boilers, saunas, stoves, fireplaces and other wood-fired appliances used for domestic heating or (in the Nordic context) (and to a far lesser extent, cooking).
} 


\section{Trends in Residential Wood Consumption and Emissions of Particulate Matter in the Nordic Countries}

\subsection{Wood burning Use and Trends}

Over the past few decades, the use of bio-fuels for domestic heating has steadily increased in the Nordic countries. Rising oil prices as well as greater climate change awareness of wood as a climate-neutral (over the long term) fuel explain much of this general trend. This is building on a long tradition of wood burning in the Nordic countries. There has also been an increase in the aesthetic appeal of wood-burning stoves, where high-design stoves and fireplaces are seen as enhancing the home environment, while providing additional heat. Wood is not exclusively burned for heating purposes: fireplaces and wood stoves also serve a social function in Nordic countries, by providing for a gathering point for family and friends.

In Denmark, consumption of wood for residential heating has risen quickly in recent years. Home-based wood burning potentially accounts for $5 \%$ of total Danish energy use and $20 \%$ of energy used for residential heating (Danish DEA 2011). Danish consumers, especially in urban areas typically use wood stoves as a supplementary heat source in order to save fuel, and hence money, on the primary heating source. Wood stoves make up the majority of biomass heating units in Denmark, though pellet stoves - which provide more stable combustion with lower emissions of hydrocarbons and particulates, including $\mathrm{BC}$ - have also become more prevalent (Figure 2.1 below). 
Figure 2.1: Use of bio-fuels and pellets in the residential sector in Denmark

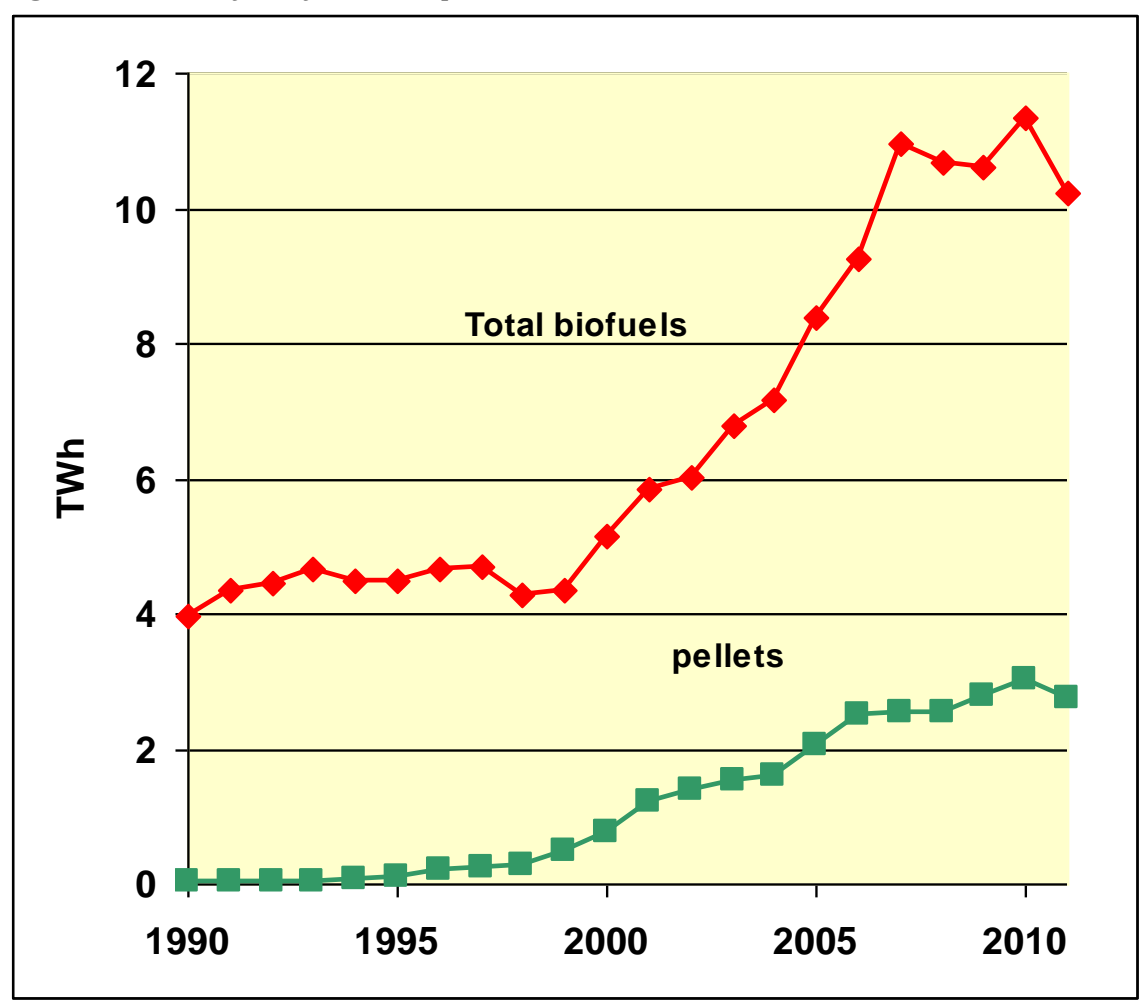

Source: Processed data from Danish Energy Agency.

In Finland, about a fifth of freestanding houses use wood fuels as their primary heating source. In urban areas however, the proportion is considerably smaller: of the approximately 60,000 houses in the metropoli$\tan$ area of Helsinki, only about $2 \%$ rely on wood for heating (Outi Kaarina Väkevä 2013). However, a large proportion of urban homes use wood for occasional additional heating or for household saunas: $80 \%$ of detached houses in the metropolitan area are equipped with wood stoves for sauna or heat, as are many new apartments (Outi Kaarina Väkevä 2013). Heat-retaining masonry fireplaces are the most commonly used in new houses, with the use of open fireplaces on the decline. Since 2000, overall use of biofuels in Finland has increased by approximately $40 \%$ (see Figure 2.2 below). 
Figure 2.2: Use of wood/bio-fuels in the Residential sector in Finland

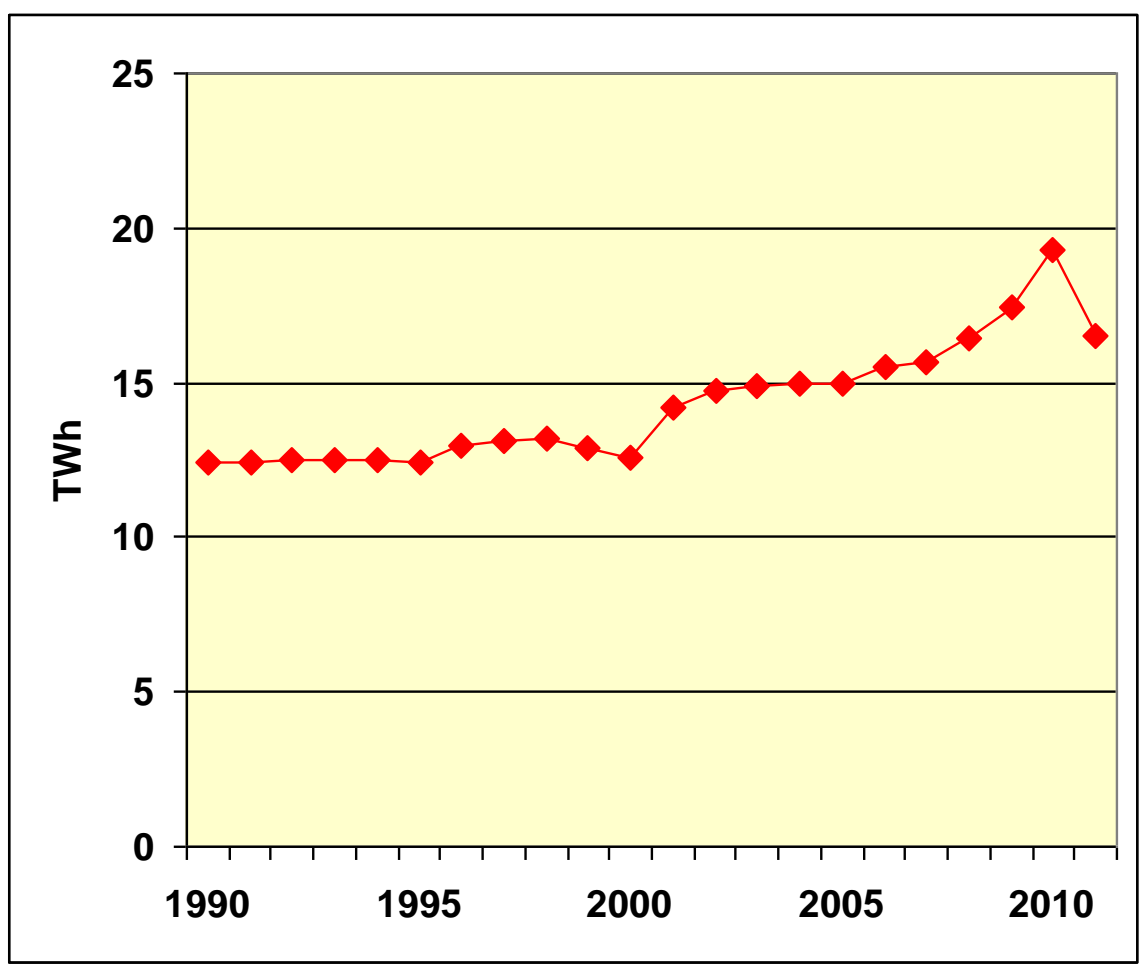

Source: Processed data from Statistics Finland.

In Norway, wood fuel is the second most important source of energy for household heating, after electricity (which in Norway is primarily hydro), and has shown a stable or steadily increasing trend. Wood fuel accounted for $17 \%$ of the total energy supply in 2010 (SSB 2013); however because it is harder to achieve efficient use of energy from wood than other fuels, wood burning accounted for only $10 \%$ of net useful energy. Wood consumption in Norway (and indeed all four Nordic countries) declined in 2011 due to warmer than normal temperatures and in some areas an unexpected shortage of wood; while somewhat colder than temperatures in 2010 led to a high peak in all four countries that year. 
Figure 2.3: Use of wood/bio-fuel in the residential sector in Norway

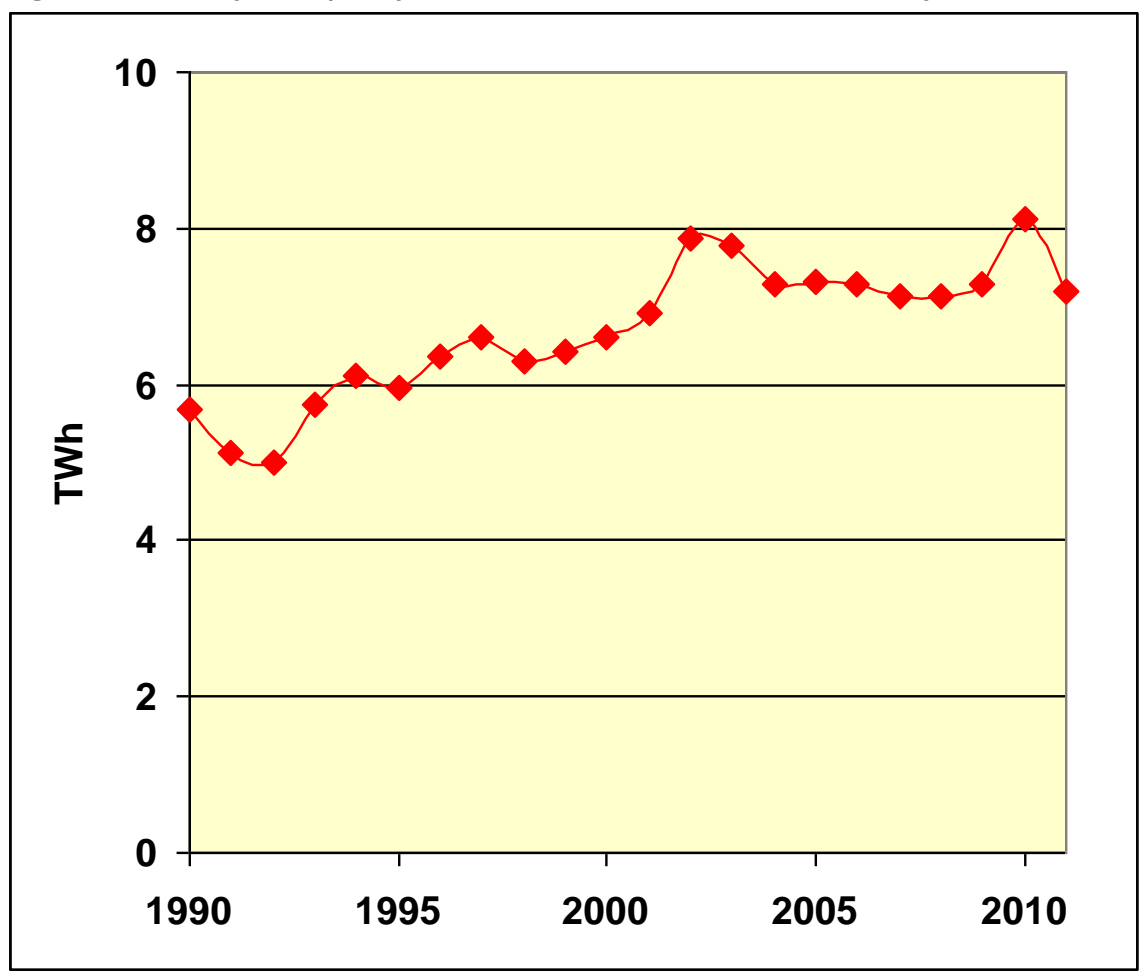

Source: Processed data from Statistics Norway.

In Sweden, wood burning for residential purposes has increased by approximately $65 \%$ since 2000 - a rise due mainly to steep growth in the use of stoves for secondary heating. (see Figure 2.4). The use of boilers for primary heating has remained relatively constant or decreased slightly over this period (see Figure 2.5 ). In 2010, approximately $60 \%$ of wood-burning boilers in Sweden were equipped with improved technology such as heat accumulators. Unfortunately, there are no similar national statistics available for frequency of improved stoves. Overall, energy from wood-fuels made up $11 \%$ of the total energy supplied in the residential sector in 2010 (Energimyndigheten 2012). 
Figure 2.4: Use of Biofuels and pellets in the Residential sector in Sweden

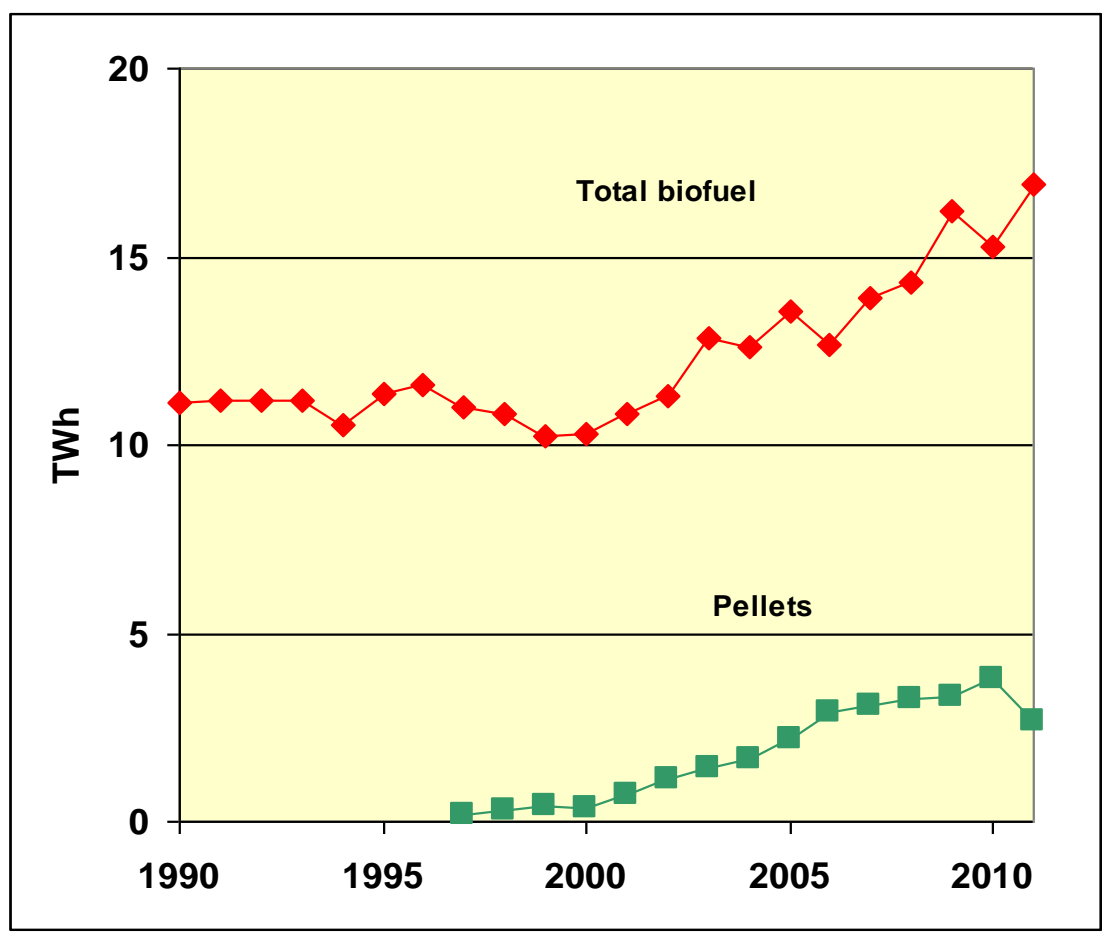

Source: Swedish Energy Agency.

Figure 2.5: Number of fireplaces, stoves and boilers in Sweden

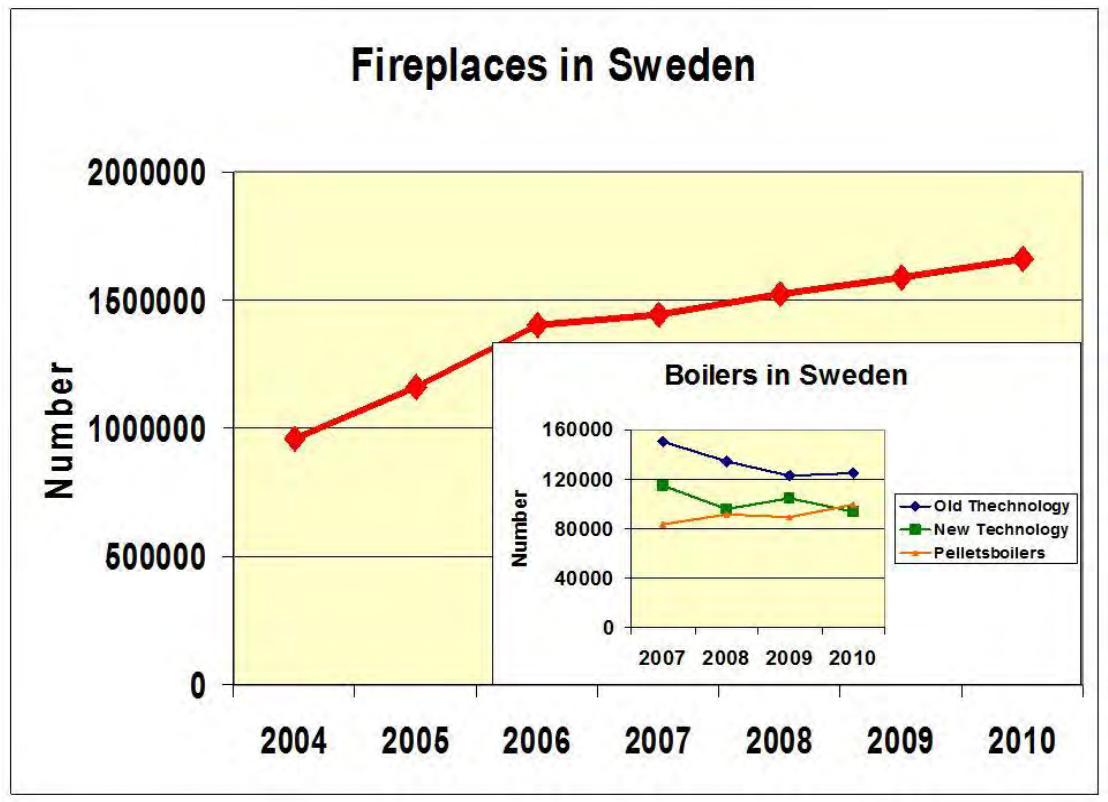

Source: Processed data from Swedish Civil Contingencies Agency. 


\subsection{Emissions of Particulate Matter}

Emissions of particulate matter PM2.5 (particles with size less than 2.5 micrometers) are subject to a substantial uncertainty due to a lack of exact knowledge about for example the total wood consumption, models and age of stoves and boilers, wood consumption distributed between these units, and emission factors under real life conditions. They also include different kinds of measurement methodologies. These uncertainties should be kept in mind when comparing data from different countries or sources.

Figure 2.6 below shows the trend in emissions of PM2.5 from the residential sector in the Nordic countries. It is difficult to draw any definite conclusions about the trends in emissions of black carbon from burning wood in the different countries. However, he figure indicates that the trends in the Nordic countries are different. If this is due to differences in methodology for calculating emissions, e.g. measurement methods based on emission factors, or differences in the use of various bio-fuels in the residential and service sector needs to be studied further.

Figure 2.6: Emission of particulate matter PM 2.5 in the residential sector in Nordic countries

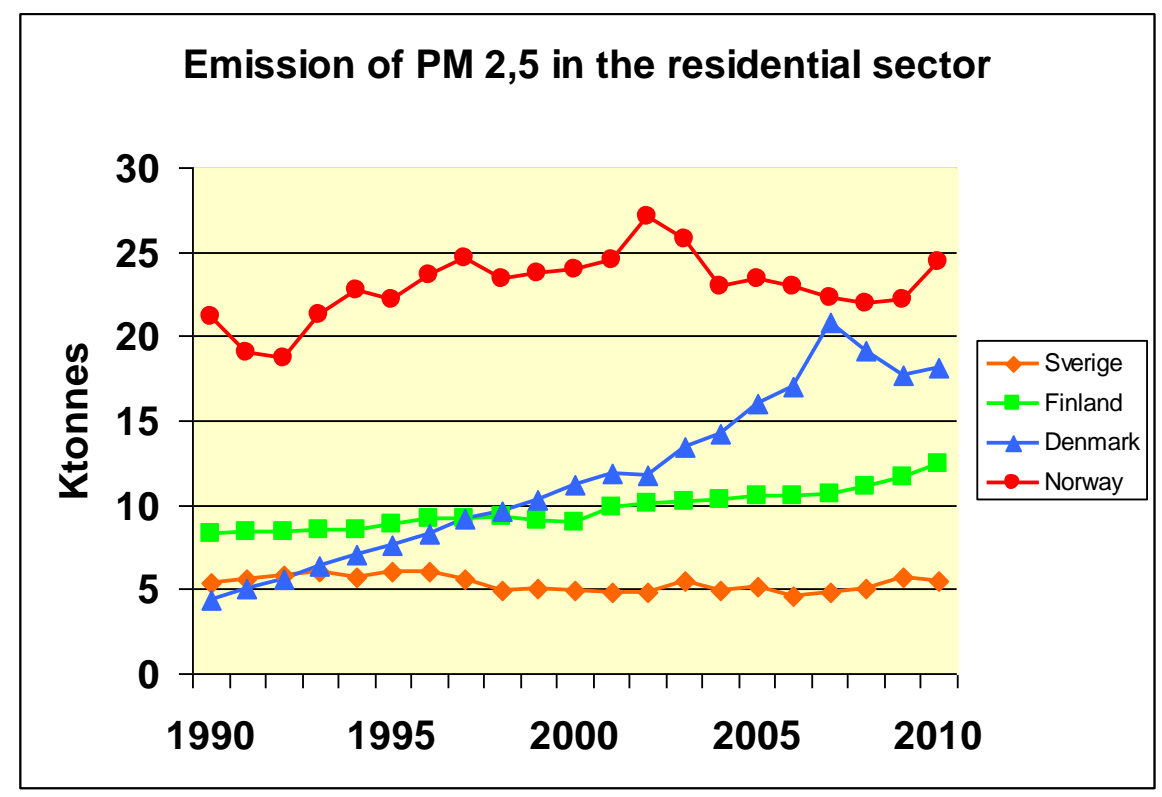

Source: Processed data from EEA homepage (Denmark), Finnish Environment Institute, Statistics Norway and Swedish Environment Protection Agency. 
By comparing the use of wood in the Nordic countries with the reported emissions one can observe that emission factors are significantly higher in Norway than in Sweden (Table 2.1). The differences cannot be explained by differences in equipment installation or use of bio-fuels, but must be due to due to reasons which are currently not fully understood.

Table 2.1: Average emission factors for small scale wood burning used in Nordic countries in 2010

\begin{tabular}{ccccc} 
& Denmark & Finland & Sweden & Norway \\
\hline Ton /TWh wood-fuel & 1,601 & 646 & 357 & 3,006 \\
\hline
\end{tabular}

\subsection{New technology reduces emissions}

It is possible to develop new technology for both higher efficiency and reduced emissions including emissions of Black Carbon-soot. Automatic control technologies is not so common yet and could be further developed. By utilizing advanced control technology and inexpensive sensors emissions could be further reduced. The combustion chamber geometry also plays a role for the flame dispersion and retention time as well as keep a high temperature in the main combustion chamber. A developed geometry design also enables the delivery of secondary and tertiary air supply. Further development of the burner heads in wood pellets boiler and stoves and refined fuel delivery systems are examples of potential technology improvements.

Another starting point for achieving lower emissions is to avoid starting the fire too often because starting up is a critical phase for the generation of soot and other pollutants. This can be achieved by accumulating and storing heat in some way. Heavy stove structures where for example heat is accumulated in a stone material or using water tank accumulators for hot water which can store heat over several days are recommended. When using an accumulator tank there is no need to choke the air supply in order to meet the varying heating demand of the house. This also leads to less pollution.

As an example the EU project "Future BioTec" has developed guidelines for stoves showing how emissions can be further limited by use and design of the appliances. (Future BioTec 2012). 



\section{Responses to Wood Burning Emissions in the Nordic Countries}

\subsection{Historical Background}

The recognition of wood burning emissions as an environmental problem in the Nordic countries began in the 1970s. The effects of inefficient woodburning technology, combined with a widespread lack of knowledge of proper fire-making practices, contributed to a growing concern about the impact of residential wood burning on ambient air pollution, particularly in urban areas.

Complaints about smoke from domestic wood burning became more common after the energy crisis in the 1970s, when wood use increased sharply. Many households installed boilers that could use both wood and fuel-oil. Measurements at the time revealed very high emissions of soot, carbon monoxide, particulate matter, and organic carbon pollutants such as tar. Authorities also observed increasing chimney fires, primarily because frequent inefficient wood burning creates higher flue-gas temperatures than fuel oil burning.

As a result, in the 1980s all Nordic countries began taking steps to introduce emission limits for air pollutants from wood burning, along with measures to improve efficiency and thereby reduce the risk of high flue gas temperature and fires in chimneys. At the same time, awareness began to grow about the adverse health effects of particulate matter and other carcinogens from wood smoke, largely as a result of work carried out and disseminated by the World Health Organization (WHO). As early as 1980, the European Community established limits on particulate matter in ambient air. Since that time air quality issues have become a more prominent civic and policy concern, with municipalities in the Nordic countries and elsewhere in Europe taking a more active role in addressing the problem of high concentrations of air pollutants.

Today, the EU Air Quality Directive (Directive 2008/50/EC) is the most far-reaching instrument for improving air quality in Europe; it also covers the range of air pollutants associated with biofuel emissions. Im- 
portantly, the directive establishes clear legally binding limit values and target values for concentrations of fine particles and other pollutants.

Black Carbon consists of fine particles with sizes less than 1 micrometer. However, no country in Europe or indeed anywhere on the globe imposes limits on black carbon emissions or concentrations per se. The recent (2012) agreed revision of the UNECE's Gothenburg Protocol does mention black carbon as a constituent of particulate matter that may be addressed by signatories (UNECE 2012). The European Commission has announced that it will present an updated and comprehensive package of policies to combat air pollutants in the autumn of 2013.

\subsection{Current National Regulations on Emissions from Stoves and Boilers in Nordic Countries}

Sweden introduced emission standards for solid fuel stoves and boilers in 1988. Beginning in the late 1990s, Denmark and Norway also introduced emission standards to limit emissions specifically arising from wood burning stoves and boilers. The extent of these regulations and especially, the methods for measuring emissions vary widely. ${ }^{3}$ Thus far, Finland has not introduced any national standards for emissions from different types of bio-fuel-based heating units.

The table below shows current Nordic countries emission limits on emissions from stoves and boilers fired with bio-fuels.

\footnotetext{
${ }^{3}$ In short, Norway has adopted a measurement approach that cools the flue gases, allowing heavy hydrocarbons to condense on the particles. Measurements are carried out during the entire fuel cycle, with different burn rates. In Denmark and Sweden, testing is carried out when the boiler is fired at full output; the sample is removed from these hot flue gases. These inconsistencies in measurement methods within the Nordic countries will be addressed through a special Technical Group under this Nordic Council project.
} 
Table 3.1: Standards for emission of air pollutants from stoves and boilers in three Nordic countries. (OGC = Organic Gaseous Compounds, CO = Carbon monoxide)

\begin{tabular}{|c|c|c|c|c|c|c|}
\hline \multirow[b]{3}{*}{$\begin{array}{l}\text { Nominal heat } \\
\text { output kW }\end{array}$} & \multicolumn{2}{|c|}{ SWEDEN (1999) } & \multicolumn{3}{|c|}{ DENMARK $^{4}$ (2008) } & \multirow{3}{*}{$\begin{array}{l}\text { NORWAY } \\
\text { g/kg bio-fuel used } \\
\text { Particulates }\end{array}$} \\
\hline & \multicolumn{5}{|c|}{$\mathrm{mg} / \mathrm{m} 3$ dry gas at $10 \% 02$} & \\
\hline & OGC & $\mathrm{CO}^{5}$ & CO & OGC & Particulates & \\
\hline \multicolumn{7}{|l|}{ Manuel } \\
\hline$<50$ & 150 & & 5000 & 150 & 150 & 10 \\
\hline$>50<150$ & 100 & & 2500 & 100 & 150 & 10 \\
\hline$>150<300$ & 100 & & 1200 & 100 & 150 & 10 \\
\hline \multicolumn{7}{|l|}{ Automatic } \\
\hline$<50$ & 100 & & 3000 & 100 & 150 & 10 \\
\hline$>50<150$ & 80 & & 2500 & 80 & 150 & 10 \\
\hline$>150<300$ & 80 & & 1200 & 80 & 150 & 10 \\
\hline
\end{tabular}

Note: Norway expresses emissions limits in $\mathrm{g}$ PM/kg fuel wood; Sweden and Denmark use mg/m3 dry gas at $10 \% \mathrm{O} 2$.

Source: BBR 2013, NS 3058, BEK 1432.

The following is a brief description of each Nordic country's emissions regulations for small biomass-burning boilers and stoves, based on Table 3.1.

\subsubsection{Denmark}

Denmark implemented a system of emissions limits for stoves and boilers in 2008 based on a new ordinance passed in $2007 .{ }^{6}$ The law applies to both new and existing wood stoves and boilers installed after June 1, 2008. There are different, less stringent requirements for stoves only intended to heat a single room. The Environment Ministry also exempts straw-fired boilers in rural areas from particle emission limits. The law allows municipalities to restrict residential wood burning in small local areas based on community complaints; though there is no record that such a restriction has ever been implemented.

An updated law applying to residential wood burning emissions is currently (autumn 2013) under discussion by the Danish government. The law will, if implemented, apply stricter emission limits for new and existing wood stoves and boilers:

\footnotetext{
${ }^{4}$ For stoves maximum emissions of particulate matter are 10 gram $/ \mathrm{kg}$ wood (dilution tunnel) and $75 \mathrm{mg} / \mathrm{m}^{3}$ (directly in the flue gas pipe) at $13 \%$ oxygen.

${ }^{5}$ In the case closed fireplaces the emission of carbon monoxide must not exceed $0.3 \%$ by volume at $13 \% \mathrm{O}_{2}$. From pellet stoves, emissions of carbon monoxide must not exceed $0.04 \%$ by volume at $13 \% \mathrm{O}_{2}$. ${ }^{6}$ BEK nr. 1432.
} 
- Stoves: Max. $5 \mathrm{~g}$ total PM per kg wood or max. $40 \mathrm{mg}$ total PM per $\mathrm{Nm}^{3}, 13 \%$ oxygen.

- Boilers: Manuel feed: Max. $60 \mathrm{mg}$ total PM per $\mathrm{Nm}^{3}, 10 \%$ oxygen.

- Automatic feed: Max. 40 mg total PM per $\mathrm{Nm}^{3}, 10 \%$ oxygen.

Beginning in 2016 the limit value for wood stoves will be reduced to: Max. $4 \mathrm{~g}$ total PM per kg wood or max. $30 \mathrm{mg}$ total PM per Nm³,13\% oxygen.

The Danish EPA estimates that the new law will yield a net PM reduction of $2 \%$. However, a number of factors make the law's effects difficult to predict. First, while the majority of new wood stoves and boilers sold in Denmark today already meet the stricter requirements, the new law does not apply to existing installations and hence will not accelerate the replacement of older, more polluting, stoves and boilers. Second, while the law requires that stricter limits be applied to larger boilers and specifies tighter regulation of the placement and height of new chimneys, it weakens the ability of local municipalities to post restrictions on local residential wood burning. Under the new law, municipalities instead will be required to provide documented evidence that such restrictions will improve local air quality. This may prove difficult for municipal authorities to meet.

\subsubsection{Norway}

Norway introduced limits on emissions from wood-burning stoves, boilers and fireplaces (excluding antique/culturally significant fireplaces) in 1998. The regulations apply only to particulate matter, and limit emissions to $5 \mathrm{~g} \mathrm{PM} / \mathrm{kg}$ biofuel if the stove or boiler is equipped with a mechanism for the catalytic cleaning of flue gases. The measurements must be in accordance with Norwegian Standard NS 3058.

Norway has carried extensive stove change-out programs as an alternative to emission limits (see below).

\subsubsection{Sweden}

Prior to 1999, emissions requirements in Sweden were expressed in mg tar/MJ (Megajoules) of energy input. Boilers could emit up to $30 \mathrm{mg}$ tar/MJ, and stoves were allowed a limit of $40 \mathrm{mg}$ tar/MJ. The current emission limits follow the European standard EN 303-5 established in June 1999, based on measurements taken directly within the flue gas. This standard requires that solid-fuel boilers with a manual fuel supply system include a heat accumulator (or its equivalent) to allow for high 
energy efficiency. In the case of stoves and fireplace inserts, the emission of carbon monoxide (CO) must not exceed $0.3 \%$ volume at $13 \%$ supply of oxygen $\left(\mathrm{O}_{2}\right)$. Emissions of carbon monoxide (CO) from pellet stoves must not exceed $0.04 \%$ volume at $13 \% \mathrm{O}_{2}$. The energy efficiency should in these cases be more than $60 \%$ for stoves, $50 \%$ for fireplace inserts and $70 \%$ for pellet stoves, with testing carried out in accordance with European Union standards.

Some important limitations exist on these regulations: first, the standards do not apply to existing stoves or boilers sold on the second-hand market. Second, the requirement for emissions of carbon monoxide (CO) does not apply to open fireplaces and traditional tile stoves ("kakelugnar") intended primarily for leisure, nor to emissions from kitchen stoves.

\subsubsection{Finland}

Finland has never introduced any emission standards.

\subsection{Incentive Programs for Improving the Environmental Impact of Stoves and Boilers}

Over the past several years, Nordic countries have implemented various programs aimed at addressing the negative effects of residential wood burning on local air quality and climate. The efforts have included incentive programs for upgrading or swapping out old wood-burning stoves and boilers in favour of cleaner-burning, more efficient technology. There have also been programs to encourage a transition from oilburning to renewable biofuels in the residential heating sector. The following is a summary of country-specific initiatives.

\subsubsection{Denmark}

In 2008, Denmark introduced a scrapping payment for old wood boilers (i.e. those installed before 1980), based on the Danish environmental Ordinance BEK nr 1432 (from December 2007). Individuals received a grant of up to 530 Euros if they replaced an old wood boiler with a new boiler that fulfilled the emission limit values set down in the ordinance, or used an alternative heat source. A total of 2.93 million Euros was set aside for scrapping payments between 2008 and 2009 (Kåre PressKristensen 2013). 
This program led to the replacement of an additional 3,500 boilers, approximately doubling the number of boilers that would have been replaced in a usual 1-2 year period. Because old wood boilers are the most polluting heat source per GJ heat, the payment plan produced an immediate reduction in emissions - the net effect of which depends on the type of replacement heat source installed. Over the 1-2 year duration of the program, the scrapping payment is estimated to have achieved a total reduction of 1,500 tons PM2.5, and 500 tons BC (Kåre Press-Kristensen 2013).

Despite these short-term gains, the program was criticized by some within the environmental community for not requiring that payment recipients shift to a even cleaner heating source, such as district heating or heat pumps.

\subsubsection{Finland}

Thus far, Finland has not introduced scrapping payments or other incentives aimed at upgrading wood-burning heating units. However, the government has provided some subsidies to encourage renewable energy use in the residential sector. In 2006, Finland implemented a limited subsidy program to support households making a shift from fossil heating systems to renewable heating systems. The subsidies, averaging 1,500 Euros - or about $10 \%$ of the investment cost of the energy switch - totalled 4 million Euros annually from 2006-2008. The renewable energy grants were reintroduced in 2010; and in 2011 the total allowance for the subsidies increased to 30 million Euros. In 2013, however, the Finnish national budget included no allowance for renewable energy grants (Katja Outinen 2013).

The energy grants were intended to improve the energy economy and environmental impact of residential buildings by reducing both energy consumption and greenhouse gas emissions. Subsidies are awarded for conducting independent energy audits, external repair work (as defined in legislation), improving ventilation and heating systems, and implementing renewable energy sources.

The renewable energy grants have supported the installation of new heating systems that use pellets or firewood and those that use heat pumps. The subsidy program requires that new installations replace existing electric or oil heating systems. The grants are awarded to private individuals or companies owning year-round residential buildings. In 2012, the average grant covered only between $7-10 \%$ of documented costs, not including labour expenses. However, individual recipients were able to 
receive a tax deduction, under Finland's Income Tax Act, for the labour costs of installing the new heating system (Katja Outinen 2013).

Finland has not introduced grants to improve environmental performance of wood-burning stoves and boilers.

\subsubsection{Norway}

Norway has engaged in more extensive efforts to encourage replacement of old stoves and boilers through scrapping payment and subsidy programs. In response to air quality problems, the city of Bergen introduced a grant program to accelerate the phasing out of older boilers and stoves. The grant amounts to 5,000 NOK (approx. 600 Euros). Between 1999 and 2011, approximately 7,000 new boilers and stoves were installed as a result of this municipal effort, representing a total reduction of approximately 85 tons of particulate matter. In 2011, 65\% of the boiler stock met the Norwegian emission standards established in 1998. There are still approximately 25,000 old wood stoves in operation in Bergen, which calculations show emit approximately 335 tons of particulate matter annually (Bergen Kommune 2007, 2010, 2011, 2012).

The city of Oslo also introduced a scrapping payment plan to promote the replacement of old stoves. The grants amount to NOK 3,000 (approximately 350 Euros) for individuals residing inside the Ring Road 3 beltway and 1,500 NOK (approximately 225 Euros) for those residing outside this beltway. More than 8,000 new stoves have been installed through this grant program. The payments also include instruction in proper fire lighting practices. In Oslo, individuals can also receive funding for pellet stoves, fireplaces, and "varmepipa" 7 stoves. The grant amounts to 1.50 NOK per kWh saved, up to a maximum of $50 \%$ of the documented cost of the new technology. (Oslo Kommune 2010, Oslo Kommune mfl 2010, Oslo Kommune 2011).

In Trondheim, there was an official effort to improve the environmental performance of older boilers by providing installation of an afterburner. The afterburner consists of a sheet of metal, which is mounted in the oven where it provides a secondary post-combustion chamber. The afterburner was installed in 100 homes, and proved to perform better in smaller stoves. Laboratory experiments have shown that the in-

${ }^{7}$ A kind of masonry stove. 
stallation of afterburners could reduce particulate emissions by up to 75\% (Trondheim Kommune 2006).

KLIF, the Climate and Pollution Agency, evaluated the status of the Norwegian air quality and the need for more actions in 2010. They concluded that further reduction of emissions of particles from wood burning that goes beyond the regular replacement of old stoves gives a modest impact on air quality and focus should be on traffic emissions (KLIF 2010).

Government efforts to encourage renewable energy use and increase energy efficiency have also had some impact on the residential heating sector. In 2001, the Norwegian Parliament (the Storting) established a fund to promote renewable energy and increased energy efficiency. The fund, managed by the state-owned company Enova SF, manages 25 billion NOK; and a second fund was set up in 2013 to address climate change, renewable energy and energy conversion with an additional $\$ 10$ billion NOK. Returns from this fund, totalling $\$ 35$ billion NOK in 2013, are allocated as annual transfers to the Energy Fund. (In 2013, return on capital provided a total of 996 million NOK to the Energy Fund).

Through this fund, individuals can receive subsidies of $20 \%$ (up to $4,000 \mathrm{NOK}$ ) to buy a new pellet stove, and up to 10,000 NOK for a new pellet boiler. Most of the projects supported in the housing sector, however, have supported measures aimed at reducing energy consumption, rather than limiting PM emissions per se (ENOVA 2013).

Likely due to all these various change-out programs, Norway by 2011 had $47 \%$ of households using stoves with environmentally improved technology - $29 \%$ more than in 2002.

\subsubsection{Sweden}

Municipal authorities in Sweden have long had to deal with environmental problems related to small-scale wood burning. Significant failings were identified in the so-called "combi-boilers" installed in the 1970s; these boilers allow users to combine (alternatively use) wood, oil and/or electricity as the primary energy source. Because fuel input must be in line with heat demand, it was customary for air supply to be cut off so that the power output from the boiler could better answer the heating demand from the house. When accumulator tanks are attached, the boiler is better able to regulate fuel demand and heat output. The boiler can burn at maximum power until the accumulator is full of hot water, thus allowing the boiler to store energy until the heating demand requires it. In the 1990s, Sweden designated grant money for increasing the instal- 
lation of accumulators for boilers; this investment was also part of an effort to address unemployment during the recession.

In 1998, Sweden established a Local Investment Program (LIP) aimed at increasing environmental protection activities at the local level, and in 2003 LIP was replaced by the Climate Investment Program (KLIMP) geared toward helping Sweden achieve its greenhouse gas targets. Both of these initiatives addressed the climate impacts of residential wood-burning, although black carbon was not included as it was not known as a climate forcer at that time. Older boilers, in particular, emit high quantities of methane, a powerful greenhouse gas. Under the programs, approximately 30 municipalities provided grants to individuals to install new boilers and stoves. In some instances, grant recipients were required to take part in a course on good wood-firing practices. The grants, totalling 36 million Swedish kronor, ranged from $12 \%$ to $35 \%$ of the approved cost of the upgrade (Naturvårdsverket 2009, 2013). The KLIMP program ended in 2008.

\subsection{Information Campaigns}

The polluting effects of residential wood burning are not only a result of outdated and inefficient technology; human error and behaviour also play a major role. Detailed measurements taken from chimneys by Danish and Swiss researchers reveal that particulate $\left(\mathrm{PM}_{2.5}\right)$ emissions can increase up to 30 -fold if the stove is operated improperly, for instance, if there is insufficient air supply (see for instance Nussbauer et al. 2008). If more serious mistakes are made - such as burning material other than dry firewood or overloading the stove with too much firewood - emissions may increase up to 250 times. According to Danish EPA, $\mathrm{PM}_{2.5}$ emissions can be reduced by up to $80 \%$ if operators use very small pieces of dry wood carefully stacked as a tower inside the combustion chamber and ignited in the top.

Campaigns aimed at teaching users how to operate stoves and boilers correctly can thus significantly reduce the environmental impact of residential wood burning. Over the last five years, the Danish EPA and Danish chimney sweeps have run an intensive educational campaign on Danish television, the internet and in newspapers, to inform stove and boiler users about how to burn wood in their homes in an environmentally responsible way. In Finland, the Central Association of Chimney Sweeps provides brochures instructing customers on how to use the fireplaces and how to burn wood correctly. The sweeps may also pro- 
vide on-site guidance to consumers regarding best practices for operating residential stoves and boilers. This information is provided on a voluntary basis, depending on the chimney sweep's availability. In Sweden general advice on how to burn effectively have also been developed and disseminated at the local and national level.

\subsection{Environmental Legislation Supporting Reductions of Residential Wood-Burning Emissions}

The four Nordic countries have a number of laws relating to environmental and health protections that can contribute - directly and indirectly - to biofuel emissions from household stoves and boilers. An overview of this legal landscape may provide a useful framework for designing future actions on black carbon and other PM pollutants from small-scale wood burning.

\subsubsection{Denmark}

Denmark's Environmental Protection Law (LBK $n r$ 879), effective from 2010, includes several objectives that could broadly encompass the problem of residential wood-burning emissions. The law is intended to:

- Prevent and control pollution of air, water, land and soil as well as vibration and noise.

- Provide hygienic, reasoned rules relevant to the environment and to humans.

- Limit the use and waste of raw materials and other resources.,

- Promote the use of cleaner technology.

- Promote recycling and reduce problems associated with waste management.

Paragraph 42 of the law document includes a more specific reference to potential environmental hazards related to energy use.

"If activities, including private and public activities, and units for energy production ... result in unhygienic conditions or a substantial pollution ... the responsible authority can require that the pollution must be reduced e.g. by requiring that specific measures be taken." 
This paragraph is primarily aimed at reducing local pollution in neighbourhoods, which could apply to particle emissions from household burning. However, some enforcement challenges are apparent in the law's current form. For one, the municipal authority must prove that the pollution is substantial in order to require reductions, but such authorities do not have the necessary measuring devices to determine pollution levels. In addition, pollution from wood burning most often occurs in the evenings and during weekends when the municipal offices are closed. Finally, it may be impossible to identify which chimney is the "polluting" chimney, given that many people in a neighbourhood are likely to be burning wood in their homes at the same time.

Denmark's Heat Supply Act (LBK nr 1184 af 12/12/2011) also has relevance for the household stove and boiler use. The law aims to "promote socio-economic and environmentally friendly use of energy to supply buildings with heat and hot water and to reduce the use of fossil fuels in the heat supply. The heat supply should promote combined heat and power production."

Denmark uses combined heat and power plants (CHP) which use $30 \%$ less fuel than separate heat and electricity production systems, making district heating a desirable option for a majority of Denmark's population. ( $60 \%$ of households use district heating). The law has thus prevented emissions from residential wood burning from reaching even higher levels than they are at present. (In some districts, the opposite effect has occurred; high prices for district heating have encouraged more households to use wood-fuelled stoves and boilers.)

Paragraph 14 of the Heat Supply Act states:

"If required to accomplish the heat supply planning, the municipal council can decide that some heat sources cannot be installed in existing or new households in a local area. The minister of climate, energy and buildings can require the municipal council to decide this."

While this paragraph could potentially provide a check on residential wood burning, there is no record of its use to prohibit installation of new wood stoves or boilers.

\subsubsection{Finland}

In Finland, a number of laws - including the Land Use and Building Act (132/1999), the Environmental Protection Act (86/2000) and the Health Protection Act (763/1994) - can apply to small-scale wood burning. 
The Health Protection Act aims to maintain and promote public and individual health and to prevent, reduce and eliminate pollution that can cause health hazards. According to Paragraph 2.

"an activity that affects habitat should be carried out so that the occurrence of nuisance is prevented as far as possible. Among others, small-scale woodburning is considered as such an activity. Small-scale burning must not emit pollution in such a way as to cause a nuisance in the neighbourhood."

Under this law, the local health authority may require those causing the inconvenience to correct or limit the sanitary inconvenience. The Health Protection Agency also has the right to perform inspections and surveys in such cases. The person conducting the inspection is also entitled to receive the necessary information on buildings and equipment and to carry out measurements and take samples.

The Product Supervisory Authority (Social och hälsovårdens produkttillsynscentral) has issued instructions regarding when municipal authorities should intervene against nuisance wood burning (STTV 2008). People who are disturbed by wood burning are encouraged to keep a diary to be able to document and confirm the problem. The matrix below (see Table 3.2) shows the conditions under which action should be taken. In some cases the Administrative courts have made decisions that have forbidden the use of separate wood stoves or boilers.

\begin{tabular}{|c|c|c|c|c|}
\hline \multicolumn{5}{|l|}{ Frequency of occurrence of smoke } \\
\hline $\begin{array}{l}\text { Continuous; up to } 4 \text { days / week and over } 3 \text { hours } \\
\text { at a time }\end{array}$ & 3 & Yellow & Red & Red \\
\hline $\begin{array}{l}\text { Often; } 2-3 \text { days / week and over } 3 \text { hours at a } \\
\text { time }\end{array}$ & 2 & Green & Yellow & Red \\
\hline \multirow[t]{3}{*}{ Seldom; 1 day/week and over 3 hours at a time } & 1 & Green & Green & Yellow \\
\hline & & 1 & 2 & 3 \\
\hline & & $\begin{array}{l}\text { The smell is } \\
\text { mild }\end{array}$ & $\begin{array}{l}\text { The smell is } \\
\text { moderate }\end{array}$ & $\begin{array}{l}\text { The smell is } \\
\text { heavy }\end{array}$ \\
\hline
\end{tabular}

Source:

Red: Nuisance, caused by smoke is a very significant to health

Yellow: Nuisance, caused by smoke is significant to health

Green: Nuisance, caused by smoke is fairly insignificant to health

In paragraph 5, the Environmental Protection Act (2000/86) states: operators must have sufficient knowledge of their activities' environmental impact and risks and of ways to reduce harmful effects (knowledge re- 
quirement) and if the activities cause or may directly result in environmental pollution, the operator must take the appropriate action without delay in order to prevent pollution, or, if pollution has already resulted, to reduce it to a minimum (obligation to prevent pollution).

Finally, paragraph 49 of the Land Use and Building Regulation states that "the building must not compromise hygiene or health...through the emission of toxic gases or dangerous particles or gases in the air, dangerous radiation, pollution or poisoning of the water or soil, inadequate disposal of waste water, smoke and solid or liquid waste and moisture in the building elements or surfaces in the building."

Finland has not used this regulation to address emissions of air pollution from small scale burning. Instead, the government is awaiting new regulations for wood burning under the EU Directive on Ecodesign.

\subsubsection{Norway}

In Norway, the Pollution Control Act (1981-03-13 No. 06) is intended to protect the environment from pollution, to reduce existing pollution, and to reduce the amount of waste and promote better waste management. The applicability of this law to the problem of residential wood burning is limited in that "typical contaminants from homes and cottages" are permitted to the extent that specific provisions laid out in paragraph 9 of the Law do not cover them.

The section of the law addressing local air quality states that owners of buildings that violate emission limit values should implement necessary measures to mitigate the problem. Owners of wood-burning stoves and boilers are only required to limit emissions when municipal authorities notify residents of emission limits. Municipal regulations may not be enforced when the local power grid is overloaded. The use of this law to actually limit wood burning does not however appear to have occurred in practice.

\subsubsection{Sweden}

In Sweden, there are two sets of regulations - the Planning and Building Act (2010:900) and the Environmental Code (1998:808) - that have relevance for managing emissions from household wood burning.

The Environmental Code provides a legislative framework for promoting sustainable development. The general rules in the law apply to everyone, including individual property owners who burn solid fuels. These individual operators are required to demonstrate to regulators 
that the burning of solid fuels does not negatively impact human health or the environment.

Paragraph 1 of Chapter 9 states that "environmentally hazardous activities" include using land, buildings or facilities in a way that may cause harm to human health or the environment through emissions or through pollution of land, air, water or groundwater. Under this definition, small-scale wood burning can be classified as an environmentally hazardous activity.

Paragraph 3 of Chapter 9 describes a "detriment to human health" as an activity that threatens individuals' medical or hygienic conditions in a way that is neither minor nor merely temporary. The law states that the assessment of what constitutes a "nuisance" should be based on how people generally perceive a disturbance, and that consideration should be given to those people who are slightly more sensitive than normal.

Under the Environmental Code, domestic wood burning can sometimes generate a threat to human health. Paragraph 40 of the Environment and Health Ordinance (1998:899), concerning Environmentally Hazardous Activities and Health (FMH), clarifies the application of Chapter 9 of the Environmental Code, explaining that the municipality may, if necessary to prevent harm to health, provide for temporary suspension of small-scale burning of solid fuels in certain specified areas, and authorize care and supervision of solid fuels used in heating devices.

The law grants the municipalities "supervisory authority" to ensure local compliance with the provisions and rules the Environmental Code and to take any measures that are necessary to ensure that faults are corrected. The supervisory authority in each municipality contributes to the objectives of the Environmental Code by providing advice and information to residents regarding environmentally responsible practices.

There are a number of legal cases based on the Environmental Code that land in the Swedish Environmental Court for decision. Such cases may arise from reports by neighbours who are disturbed by the effects of local wood firing. The Court has for example ruled that burning wood in urban areas should be limited because of a significant risk of inconvenience and irritation of the respiratory tract. The Court has also stated that, even though the fuel burning takes place in new modern boilers that meet current requirements for emissions, the Environmental Code still calls for precautions; the property owner is responsible for the health and environmental conditions that may be affected by his/her burning activities, regardless of whether the device has been approved or purchased and installed using state subsidies. The Court makes decisions on a case-by-case basis. In some instances, the Court has banned 
wood burning; in other cases, burning was limited to certain hours per day and/or prohibited during the summer months.

Many municipalities in Sweden seem to have established informal policies regarding wood burning or provided advice about how to light a fire. Such policies are not mandatory, but rather serve as a guiding document that provides information to residents. In some cases, the municipality has issued a mandatory limit on wood burning based on a provision within the local health care statute.

\subsection{Voluntary Eco-labelling: The Nordic Swan}

The Nordic Swan is a voluntary eco-labelling system that evaluates a product's impact on the environment throughout the product's life cycle. The label guarantees the consumer that climate and other environmental requirements have been taken into account - including that, where relevant, $\mathrm{CO} 2$ emissions and other harmful pollutants have been limited - in the manufacturing and in the functioning of the product.

The Nordic Council of Ministers established the Nordic Swan program in 1989 in an effort to promote a more sustainable environment through informed consumer purchases of high quality products and services.

The Nordic Swan develops criteria that categories of products must meet in order to receive the Eco-label, including criteria designed for stoves and boilers (last revised in 2010). A Nordic Eco-labelled stove must achieve a high efficiency standard and have low emissions of particles, carbon monoxide (CO), and organic gaseous carbon. The manufacturer must also ensure that the instruction manual contains comprehensive information and recommend that a qualified fitter install the stove.

The Nordic Swan voluntary requirements for stoves and boilers are of course more stringent than the Norwegian, Swedish, Danish and Finnish national regulations. Norwegian and Danish law regulations only require particle tests and Swedish regulations only require hydrocarbon tests. Finland as noted above has no emission requirements.

The Nordic Eco-label is well-known and highly accepted among both producers and consumers in the Nordic countries; a recent Nordic market survey showed that in all five countries, 94\% recognized the Swan trademark as an Eco-label. Below are the emissions requirements from Eco-labelled stoves and boilers in addition to additional environmental performance criteria. The Nordic Swan does not currently include requirements for black carbon. 
Table 3.3: Emission Limit Values for Nordic Eco-labelled boilers $<300 \mathrm{~kW}$

\begin{tabular}{|c|c|c|c|}
\hline & \multicolumn{3}{|c|}{ Nominal heat output kW } \\
\hline & Automatic & Manue & \\
\hline \multirow[t]{2}{*}{$\mathrm{mg} / \mathrm{m} 3$ dry gas at $10 \% \mathrm{O} 2$} & $<300$ & $<100$ & $>100$ \\
\hline & & & $<300$ \\
\hline OGC & 25 & 70 & 50 \\
\hline $\mathrm{CO}$ & 400 & 2000 & 1000 \\
\hline Particles & 40 & & 70 \\
\hline NOx & 340 & & 340 \\
\hline
\end{tabular}

Source Nordic Swan 2007.

Table 3.4: Emission limits values for Nordic Eco-labelled stoves, at $13 \% \mathbf{0}_{2}$ dry gas. The requirement applies at nominal heat output unless specified otherwise. $\mathrm{X}$ means a weighted mean value of test results by given outputs within burn rate categories

\begin{tabular}{|c|c|c|c|}
\hline & $\begin{array}{l}\mathrm{OGC} \\
\mathrm{mg} / \mathrm{m} 3\end{array}$ & $\begin{array}{l}\mathrm{CO} \\
\mathrm{mg} / \mathrm{m} 3\end{array}$ & $\begin{array}{l}\text { Particulates } \\
\mathrm{mg} / \mathrm{m} 3\end{array}$ \\
\hline $\begin{array}{l}\text { Hand fed slow heat release } \\
\text { appliance }\end{array}$ & 120 & 1,200 & 50 \\
\hline Hand fed sauna stove & $\begin{array}{l}120 \\
\mathrm{mg} / \mathrm{m}^{3}\end{array}$ & $\begin{array}{l}1,700 \\
\mathrm{mg} / \mathrm{m}^{3}\end{array}$ & 100 \\
\hline $\begin{array}{l}\text { Hand fed stove for tempo- } \\
\text { rary firing or inset stove }\end{array}$ & 120 & 1,700 & $\begin{array}{l}4,0 \text { ( } x \text { for up to } 4 \text { heat outputs) } \\
8,0 \text { (for each individual test) }\end{array}$ \\
\hline $\begin{array}{l}\text { Hand fed stove for contin- } \\
\text { uous firing }\end{array}$ & 60 & 800 & $\begin{array}{l}3,5 \text { ( } x \text { for up to } 4 \text { heat outputs) } \\
7,0 \text { (for each individual test) }\end{array}$ \\
\hline $\begin{array}{l}\text { Mechanically fed pellets } \\
\text { stove }\end{array}$ & $\begin{array}{l}60 \text { (nominal heat output) } \\
60 \text { ( } x \text { for partial heat } \\
\text { output } 1 \text { and } 2 \text { ) }\end{array}$ & 800 & $\begin{array}{l}3,5 \text { ( } x \text { for up to } 4 \text { heat outputs) } \\
7,0 \text { (for each individual test) }\end{array}$ \\
\hline
\end{tabular}

Source Nordic Swan 2010.

Manufacturers that have received Nordic Swan approval include

\begin{tabular}{ll}
\hline Stoves & Boilers \\
\hline Aduro A/S & Baxi AB \\
HWAM A/S & Effecta Pannan AB \\
Dovre A/S & \\
Jötul A/S & \\
Keddy AB & \\
Lotus Heating Systems A/S & \\
Morsö Jernstöberi A/S & \\
NIBE AB Brasvärme & \\
RAIS A/S & \\
Scan A/S & \\
TermaTech A/S & \\
Varde Ovne A/S & \\
\hline
\end{tabular}




\section{International and Other Initiatives to Reduce Emissions}

Over the past few decades, growing awareness of the climate and health threat posed by energy-related pollutants has given rise to a range of international efforts to curb emissions of particulates (PM 10, PM 2.5) as well as greenhouse gases. A number of these initiatives have the potential to reduce the environmental impact of residential wood burning in Nordic countries - helping to protect both local air quality and the Arctic climate. The following is a preliminary overview.

\subsection{The Ecodesign Directive (2009/125/EC)}

The European Union's Ecodesign Directive establishes a framework for setting mandatory ecological requirements for energy-related products produced and sold in the EU member countries. The aim of the directive is to optimize the energy performance and minimize negative environmental impacts of products, while maintaining or improving their functional qualities. The requirements must be measurable and quantifiable.

Under the Ecodesign Directive, product-specific EU-regulations are directly applicable in all EU countries. In every such Directive, there are specified dates from which the requirements shall apply. Once the regulation comes into force, no additional or more stringent requirements can be introduced in the EU (or in the case of Norway, EEA) member countries.

A proposal for emissions limits on stoves and boilers was presented for approval in July 2013. The requirements apply to wood boilers, pellet boilers/burners, kitchen stoves, coke furnaces, wood stoves, fireplace inserts, tiled stoves and masonries. The feasibility study included boilers up to $500 \mathrm{~kW}$ and thus also includes property boilers and small district heating plants. The proposal is currently under negotiation, and incorporates energy efficiency standards and emission limits for particulate matter (PM), carbon monoxide (CO), nitrogen oxides and organic gase- 
ous compounds (OGC). According to the proposal the new standards should enter in to force in 2018. There are no planned requirements for black carbon.

The proposed emissions limit values by the EU-COM are close to the current Nordic Swan requirements but higher than the best available stove on the market.

\subsection{The Convention on Long-Range Transboundary Air Pollution (CLRTAP)}

Since 1979, the CLRTAP has operated under the United Nations Economic Commission for Europe to address some of the major environmental problems of the region. The Convention has been extended by eight protocols that identify specific measures that member Parties can take to cut their emissions of air pollutants.

In 2012, the Gothenburg Protocol of the Convention was amended to include commitments to reduce particulate matter emissions. This amendment also includes mention of black carbon emissions - stating that when Parties are implementing measures to achieve national targets for PM, they should prioritize (to the extent appropriate) actions that can significantly reduce black carbon in order to optimize benefits to human health and the environment and to help mitigate near-term climate change.

Practical implementation of the revised Protocol, through Technical Annexes and guidance (such as Best Practices, Best Available Technologies) documents provided by a variety of working groups under the Convention, is currently under development. The revised Protocol will most likely come into force in 2015.

\subsection{The Arctic Council}

The Arctic Council formed in 1996 as a high level intergovernmental forum aimed at promoting cooperation, coordination and interaction among the Arctic states - with involvement of Arctic indigenous communities and other Arctic inhabitants - on shared issues, particularly those relating to sustainable development and environmental protection of the Arctic.

Many of the Arctic Council's activities address the environment, climate change and biodiversity. In 2009, the Council created a Task Force 
on Short-lived Climate Forcers specifically to address black carbon emissions. The Task Force and the Council's science working group, the Arctic Monitoring and Assessment Programme, both have identified black carbon from residential wood burning as an important source impacting the regional Arctic climate, in reports published in 2011 and May 2013.

The Arctic Contaminants Action Program (ACAP) provides for demonstration projects on items of environmental concern, and in November, 2012 ACAP approved a new project on the Reduction of Black Carbon Emissions from Residential Wood Combustion, co-led by Norway and Finland.

The ACAP project will:

- Compile information on black carbon emissions from residential wood combustion in the Arctic, as well as information on existing and potential abatement measures.

- Provide recommendations on cost-effective instruments and measures to further reduce black carbon emissions from residential wood combustion in the Arctic countries.

This first phase of the project will extend through 2014. The second stage will include pilot projects designed to demonstrate selected measures to reduce black carbon emissions. 



\section{Assessing the Impact of Policies and Measures}

Thus far, no comprehensive effort has been made to weigh the relative efficacy of various policies and measures aimed at reducing woodburning emissions. The following pages offer a preliminary overview of where mitigation efforts have had a relevant impact on particle pollution especially, and where they have fallen short. These have future relevance then for which approaches might prove most successful for achieving reductions in emissions of black carbon as well.

The discussion notes that serious inconsistencies between the measurement methods and emission factors used by Nordic countries present a current obstacle to make comparisons among the various and even similar approaches to reduce emissions in the Nordic countries.

\subsection{Impact on Emissions}

A simple calculation of how the use of bio fuels and emissions levels of PM2.5 have changed since 1990 provides an indication of the accumulated effect of the measures taken in a given country. Norway and Sweden have successfully broken the link between increased use of bio fuels and emission of particulate matters, while Denmark shows a different trend. In Finland emission factors have seemingly not changed since 1990. It is not possible to draw any far-reaching conclusions from these calculations however, because the differences may also consist of differences in emission calculation methodology in the Nordic countries. Note that the emission factor for PM 10 in Norway, for example, is nearly factor of 10 higher than the emission factor used in Sweden. 
Figure 5.1: The development of the use of bio-fuels and emissions of particulate matter (PM 10) in the Nordic countries 1990 - 2010. Index = 100 the year 1990

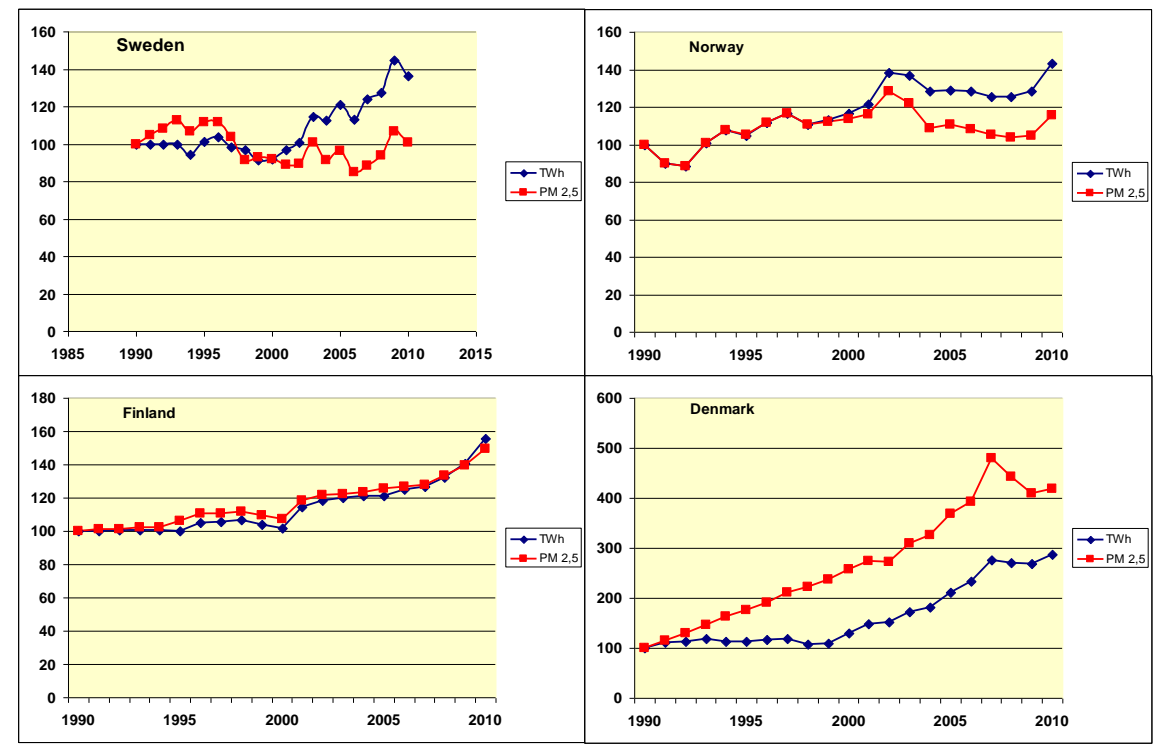

Source: Processed from data from Nordic countries.

\subsection{Impact of Scrapping Payments and Replacement Subsidies}

All four of the countries discussed in this report have had or continue to have programs providing grants to individual property owners for the replacement of boilers. There are supports are of two kinds: one for replacing old wood-burning boilers and stoves with new, the other for replacing fossil-fuel boilers with biofuel-burning units (in the context of climate change policies). In Sweden, however, the picture is also complicated as support has also been given to switch from heating with electricity to heating from another sources, like bio-fuels, in the residential sector in order to reduce constraints on the grid, as part of the energy policy decision to shut down the two nuclear reactors in Barsebäck.

The Swedish program to replace old boilers is estimated to have reduced particulate matter emissions by over 300 tons ( $6 \%$ reduction) between 1998 and 2008 (evaluated from Naturvårdsverket 2013). There are no evaluations of the impact on air quality. The costeffectiveness can be estimated at 100 SEK per kilogram decreased particle emission.

Every fourth year, the National Board of Health and Welfare conducts a countrywide survey to assess the environmental health of the population 
in Sweden. The last report, published in 2007, found that automobile exhaust was the major cause of health impacts, and the proportion of those experiencing discomfort was higher in large cities than elsewhere in the country. The proportion of the population "disturbed" by wood firing on the other hand has decreased since 1999 (Socialstyrelsen 2009).

As in previous surveys, complaints about wood burning were more common in small communities than in larger cities and suburban municipalities. The proportion dropped from just under $25 \%$ to just over $15 \%$. This trend included people who suffer from asthma or allergies. It is possible that the observed changes were due to the fact that more modern stoves and boilers were in use in 2007 than in 1999. Unfortunately however, the available data does not allow for regional comparisons; so it is not possible compare municipalities with boiler replacement programs to those without such programs.

Oslo, Norway has continued a program to replace old wood-fired stoves with new ones since 1997. 8,000 stoves have been replaced, resulting in a reduction of approximately 70 tons of particulate matter emissions (SSB 2013). The cost-effectiveness in this case can be estimated at 300 NOK per kilogram of decreased particle emission. However, there is no data indicating whether the Oslo program has increased the renewal of the stove ad boiler stock relative to other parts of the country.

The city of Bergen's grant program for stove and boiler replacement is estimated to have resulted in 7,000 new units, reducing PM emissions by 85 tons (Bergen Kommune 2011). Bergen authorities have calculated that the reduction will have positive effects on air quality on winter days during inversion events. The yearly concentration of PM emissions will be reduced by $10 \%$, and the number of residents in areas where the daily average concentrations exceed national targets will be reduced by $35 \%$.

Denmark's scrapping payment program, introduced in 2008, led to the replacement of an additional 3,500 boilers - approximately the same number of boilers that are usually replaced in the country within 1-2 years. Given that old wood boilers are the most polluting heat source per GJ of heat, the scrapping payments plan resulted in an immediate emissions reduction. The size of the reduction depends on the type of new heat source installed, but it is estimated that the payment plan produced a total reduction of around 800 tons of particulate matter. (Kåre PressKristensen 2013).

The table below provides a summary of the estimated costs and effects of the Nordic subsidy programs to replace old stoves and boilers.

As the table above shows, there are large differences in emissions per boiler and cost efficiency of the grants. The main explanation for the 
discrepancy is that measurement methods and emission factors are not harmonized among the Nordic countries. It is also likely that there are differences in the types of units being replaced. A stove has a substantially less operational time than a boiler, which supplies the entire house with heat.

Table 5.1: Costs of subsidies for replacement of old boilers and stoves in

\begin{tabular}{lrrrrr}
\hline & $\begin{array}{r}\text { Grant } \\
\text { (Euro) }\end{array}$ & $\begin{array}{r}\text { Number of } \\
\text { boilers/stoves } \\
\text { replaced }\end{array}$ & $\begin{array}{r}\text { Reduction of } \\
\text { Particulates (kg) }\end{array}$ & $\begin{array}{r}\text { Kg reduced } \\
\text { particulates/boiler } \\
\text { or stove replaced }\end{array}$ & $\begin{array}{r}\text { Euro/kg } \\
\text { reduced } \\
\text { particulates }\end{array}$ \\
\hline Denmark & $2,900,000$ & 3,500 & 805,000 & 230 & 4 \\
Norway (Oslo) & $2,600,000$ & 8,000 & 70,000 & 8 & 37 \\
Norway (Bergen) & $4,600,000$ & 7,000 & 85,000 & 12 & 54 \\
Sweden & $4,100,000$ & 2,400 & 360,000 & 150 & 11 \\
\hline
\end{tabular}

Source: Processad data from Naturvårdsverket, Miljöstyrelsen, Oslo and the Bergen Municipality

\subsection{Impact of Eco-labelling}

The Nordic Swan has had varied success in the different countries, as well as among different kinds of products. Especially in Sweden and Denmark, and to an only a slightly lesser degree in Norway, very few woodstoves are sold without the Swan mark. The Eco-label is somewhat less of a consumer demand in Finland for wood stoves, and even less for sauna stoves.

For wood boilers, Nordic Swan has not managed to create and significant consumer demand, and very few manufacturers have therefore sought the label for even newer designs that might easily meet the Swan requirements.

\subsection{Manufacturer Responses}

Meetings and conversations with representatives of various manufacturers indicate that emission limits have led to a good deal of product development in the past. These days, many manufacturers develop products based on the most stringent standards in the world in order to ensure that production will be stable for many years to come. Some representatives expressed the opinion that emission standards are too low and do not promote the best possible products on the market. They welcome upcoming calls for tighter emission limits under the EU Directive on Ecodesign. On the other hand, there are manufacturers who do not follow the on-going work under the Ecodesign Directive at all. 
Nordic Eco-label was cited by several manufacturers as also driving design, as consumers in certain markets (especially Sweden and Denmark) strongly prefer to buy Swan-marked products.

Several manufacturers expressed views on the emission measurement protocols and welcomed harmonization of methods among the different countries. Some felt that there has been too much discussion about whether hot or chilled fumes should be measured and not enough consideration of whether start- and stop-phases are used in the measurement methods. 



\section{General Assessment of Selected Policy Instruments}

\subsection{Assessment}

When it comes to policies aimed at improving the environmental impact of wood stoves and boilers the different Nordic policy instruments can be classified as:

- Administrative and regulatory.

- Economic.

- Informational.

- Research and development.

Nordic and EEA members states have in the past deployed regulatory measures in the form of technical regulations (standards) for emissions from different types of wood burning appliances; as well as general environmental legislation that can be applied to the sources (boilers, fireplaces etc.). In the case of economic instruments, the Nordic countries have introduced energy and carbon taxes that promote increased use of renewable energy, including wood burning; as well as special programs through subsidies aiming to increase the use of renewable energy and/or seeking to replace old technology for wood burning with modern technology. All countries and municipal authorities have also to varying degrees implemented information efforts to manage wood burning and thereby effectively reduce emissions of pollutants. This has been done through newsletters, campaigns on the internet, or as a condition for receiving grants to replace the wood burning appliance.

For a policy instruments to be considered successful, it should meet al.l the following criteria:

- They must be cost effective, i.e. the policy instrument should achieve such a large effect as possible for a given cost or minimize cost for a given impact.

- Contribute meaningfully to the achievement of objectives. 
- Stimulate technological development, in other words, the policy instrument also contributes to long-term, desired changes; for example, in the form of new technologies, or to structural changes in society.

Regulations determine what characteristics the stove or boiler must have, how it should be tested, marked for sale and checked for proper use once in place. Development and approval of regulations takes time, and while it can strongly drive further technical developments to meet such standards, judging the realistic speed at which innovation can occur is difficult. Most current Norwegian and Swedish regulations for wood stoves and boilers were established over a decade ago. When introduced in 1999, it reflected solely the market at that time, which meant that it did not led to incentivize manufacturers to improve design.

Primarily due to consumer demand as well as climate and air quality concerns, most Nordic manufacturers offer products that are more advanced than the current regulations require. In a market economy, companies must constantly evolve and improve; and the Nordic demand has concentrated both on environmental and aesthetic concerns to drive development. The current technical regulations have therefore played out their role as an effective instrument for promoting a long-term technology development.

However, it is possible to get around this problem if regulations are made to gradually become more stringent. This could be achieved for example by using a multi-tier system where successively more stringent standards kick in at future predefined dates. Such an approach can be combined with eco-labelling so that product performances will be visible to the consumers or with economic instruments promoting the introduction of the more stringent requirements ahead of them becoming legally binding. The proposed regulations under the EU Ecodesign Directive have such a structure. Technical regulations applied to mass-produced commodities like cars and domestic appliances can be cost-effective and driving technology if they take advantage of the potential for technological development of the products. It is also an advantage and added security for producers to know the market rules for a longer period to come.

Regulations should not be ignored as a possible measure for the long term. The current Ecodesign negotiations are the most relevant and timely regulatory efforts that may impact wood stoves and boilers through air quality concerns. Regarding European Air Quality legislation Nordic efforts should ensure that these legislatory efforts reflect the need to address wood stove black carbon emissions as a constituent of particulate matter, much as has occurred under the Gothenburg Protocol 
revision. The Ecodesign effort more directly touches on wood stoves, and there the focus should be on ensuring decisions are not taken (especially as regards testing) that could make it more difficult to add black carbon as a significant co-benefit in future. However, if black carbon emissions are not included in the implementation of the Ecodesign directive to boilers and stoves it is possible for the Nordic countries to implement additional regulations at the national level. It should also be noted that there is no proposal emission limits for saunas in the EU-COM proposed ordinance.

Nordic national governments are however somewhat limited in taking additional regulatory action to Ecodesign or NEC Directives based on air quality concerns, although black carbon and climate goals at the national level could form the basis of a regulatory effort at the national level. This may especially prove the case for boilers and saunas, which are primarily specific concerns of individual countries, Sweden (in the case of boilers) and Finland (saunas). Some sources are unlikely to be specifically addressed by Ecodesign (even if boilers are covered by the directive) or other regulatory regimes, and action at the national level less likely to be challenged on competitiveness grounds. Developments in wood boilers in Sweden clearly were driven by new requirements for accumulator tanks in the 1990's. Finland has less experience in regulation of saunas.

Over the past two decades voluntary programs such as the Nordic Swan/Eco-label have served as the primary driver of development for wood stoves and to a lesser degree, wood boilers. One manufacturer noted that "...we don't even bother to market stoves anymore that cannot get the Swan, because these days people just don't buy them." Eco-labelling and the Nordic Swan can therefore play an important role, and potentially even drive development of new measures for black carbon that might be taken on during a later iteration of the Ecodesign Directive.

Subsidies have been tried in various forms by several of the Nordic countries, from grants to reduced sales tax and other means of promoting investments in new stoves or boilers. They are often combined with information campaigns (see below), including sometimes a requirement for actual hands-on training to qualify. However, they seldom meet costeffectiveness criteria of being the lowest cost measure and will rarely fit into a long-term strategy. The players want to know that rules are stable, but subsidy programs very seldom have a long-term character. The exception is the municipality of Oslo which through its energy and climate fund has been in force in almost two decades. In some cases subsidies 
have resulted in significant and immediate effects and spurred both consumer awareness of new model and product innovation.

Subsidies may lead to various undesirable effects; for example, price increases based on the amount of subsidy. They may also primarily capture consumers who had already planned to make the investment in a newer stove. Subsidies for purchase of modern wood boilers can also be said to counter the principle that the polluter should pay. This principle was adopted by OECD in 1977 and was established as one of the original Rio 1992 principles.

At the same time, subsidies are sometimes more politically acceptable than other regulatory instruments and not surprisingly popular with both producers and consumers.

Evaluating the impact of information campaigns that train consumers how to properly light and maintain the burn cycle is more difficult. Nonetheless, it is reasonable to conclude that such campaigns should form a natural part of a national effort to limit emissions, especially aimed at operating old existing stove and boilers properly, as well as helping raise public awareness and increase knowledge of the other forms of intervention, whether subsidies, regulation or eco-labelling. The cost of such campaigns is generally low compared to other forms of intervention. In an evaluation of the Danish campaign that began in 2009 , based on a representative amount of phone interviews with people using wood stoves about $25 \%$ stated that they used the recommended technique to light a fire. The number that actually do so is in all likelihood lower, and the same evaluation showed that many people still do not operate their stoves properly. Nevertheless, most technical studies note that operator error accounts for a large proportion of black carbon and other particle pollution, and better consumer adherence to operator guidelines is clearly one of the most rapid and cost-effective ways to reduce emissions. It is necessary to repeat information campaigns to burn right at suitable intervals.

\subsection{Relevance to Future Black Carbon Measures}

Emissions of black carbon have likely declined as the requirements for emission control have tightened as regards diesel emissions, although these regulations were taken for other reasons. However, only Finland currently measures ambient black carbon emissions on a regular basis, with the smallest particles regularly measured encompassing only PM2.5 (black carbon is below the size of PM1.0). Due to differences in the for- 
mation of particles in general and black carbon all measures that reduce black carbon will also reduce PM2.5 proportionally, but measures to reduce PM2.5 may not necessarily reduce BC emissions. Although the same policy approaches may be used to achieve black carbon reductions, black carbon must be specifically targeted to ensure the most effective results from both a regional climate and health perspective.

It must also be kept in mind that apart from the clear health cobenefits from reducing the emissions of black carbon the objective of black carbon emission reductions is to reduce regional scale climate impacts of black carbon, for example black carbon emitted in or transported into the Arctic from the Nordic countries. Only addressing local air quality problems is not sufficient to achieve the necessary overall black carbon emission reductions. 



\section{Conclusions and Recommendations for Future Work}

The implications for the findings in the previous chapters for future Nordic national and joint work are summarized below. Even if the purpose of this report is not to formulate or propose regulations or legislation pertinent to black carbon, past experience, and the special character of black carbon makes it possible to indicate potential useful ways forward. These comprise two main and basic challenges: first, new and better low black carbon emitting stoves and boilers must be developed, tested and viably put on the market. Second, old inefficient stoves must be phased out. Both of these must be addressed in the future.

I

Regulation under the Ecodesign Directive will play a very important role for the development of better stoves and boilers over the next decade

Current technical regulations and emission limit values in the Nordic countries to limit emissions from stoves or boilers are obsolete, and do not give incentives for manufacturers to further reduce emissions; nor do they cover black carbon. Manufactures that act on a global market often design their products to meet the most stringent standards adopted. The forthcoming regulation on emission limits for stoves and boilers under the EU Ecodesign directive will be an important tool to reduce emissions from stoves and boilers. The new EU regulation will include energy-efficiency requirements on new stoves and boilers as well as emission limit values for CO, OGC and PM2.5. When in place, EU member countries cannot introduce more stringent standards for these substances.

In order to achieve maximum benefit emissions of black carbon must also be explicitly covered by the Ecodesign directive. This goes hand in hand with the need to establish a reliable and effective testing protocol for both PM2.5 and black carbon. The Nordic countries are in a good position to advocate such inclusion of black carbon provisions because of the fact that all Nordic countries and a number of other EU members 
are also partners in the Climate and Clean Air Coalition to reduce ShortLived Climate Pollutants.

\section{II}

The Nordic countries have the regulatory tools necessary to intervene in cases where wood burning results in poor air quality in individual cases, but their application varies and these measures have little effect on the regional emission reductions.

All countries have environment legislation that allows local authorities to intervene against local impacts of wood burning. In many cases, advice and guidelines are given to consumers by local authorities. Action may in theory also be taken by an Environment Court. However, it is difficult to see how these measures can contribute effectively to an overall reduction of black carbon emissions.

\section{III}

Nordic Eco-label can prove a powerful driver in Nordic countries to product development and consumer recognition related to black carbon.

Given its high recognition factor and ability to push requirements beyond the Ecodesign Directive and to reward best practices, the Nordic Swan can serve as a leading edge in the development of new testing requirements for black carbon, design of new stoves and future legal requirements. Development of joint protocols for testing emissions is a prerequisite to the development of such standards.

\section{IV}

While subsidies may have accelerated some change-outs in local municipalities, their overall impact in comparison with municipalities without subsidies has not been studied. It is therefore difficult to calculate whether any additional air quality benefit from subsidies has occurred. Subsidies on a national scale such as a black carbon reduction intervention would certainly prove expensive, so must be considered primarily as a tool to speed development and adoption of more innovative designs.

Introducing subsidies for products that are already commercially available in the markets is rarely cost effective. Instead, there is a risk that the funds go to households that had already planned to replace their stove or boiler. Subsidies for new and better technology are preferable but there is also a risk that subsidies distort markets. 
$\mathbf{V}$

It is technically possible to accelerate the development of stoves and boilers so that emissions of both black carbon and PM2.5 can be pushed down, and the user's skill to burn a fire plays a minor role.

It is possible to develop the technology for both higher efficiency and reduced emissions. Further development of the burner heads in wood pellets boiler and stoves, refined fuel delivery systems and improved combustion chamber designs are possible technological advances. By using advanced control techniques together with inexpensive sensor technology emissions could be further reduced.

Models that use whole wood are of greatest interest, as these will remain the basic fuel for many consumers.

V

There are significant uncertainties in emission measurements for both PM and $B C$, which also is reflected in comparative data from the Nordic countries.

In spite of the fact that stoves and boilers sold in the Nordic countries are often of the same brand, the way emissions are measured and reported vary between countries, as do emission factors used to estimate the amount of particulate matter. To some extent it can be explained by the underlying testing methods being different. There is also need for better statistics over the number of installed stoves and boilers and the amount of wood used by different types of installations. This will also apply to measurements of emissions of black carbon.

It is important to recognize that testing protocols should be compatible across the transport sector, industry sector and the residential sector in order to assess their relative contributions to the overall emissions of BC. The Nordic Countries have the opportunity to influence the development of harmonized testing protocols for measuring emissions of BC and PM2.5, both within the Nordic Swan and the Ecodesign process. This is particularly important regarding the application of the Ecodesign Directive to domestic heating appliances.

VII

Effective policy interventions possible and further cooperation needed to develop a long-term strategy.

Technology development should be further promoted. It should not rely entirely on research and development, but other forms of stimulus are needed to bring new products to market. Industry and market actors have a key role in developing and putting new technology on the market.

Additional measures should be considered if the natural change out of older equipment is not expected to be sufficient to achieve the desired 
goal. This could for example be done by setting deadlines for using particular kinds or models of stoves. Other ways of promoting the introduction of new and better products would be by using differentiated taxes and other economic instruments.

In conclusion it would be possible to develop legislation and regulations addressing black carbon and PM2.5 for the dual purpose of reducing black carbon emissions reaching the Arctic and Black Carbon/PM2.5 causing local health problems. There is scope for further work for under the auspices of the Nordic Council of Ministers, nationally, and in other international forums. The current work on the implementation of the Ecodesign directive is especially important to the Nordic Countries. In order to reach the political goals set up by the Nordic countries such broader efforts should be initiated quite rapidly. 


\section{References}

BBR 2013; Boverkets byggregler 2013 www.boverket.se

BEK 1432 Brændeovnsbekendtgørelsen 1432, Miljöministeriet i Danmark 2007 www.retsinformation.dk

Bergen Kommune 2007; Bergen Kommune, Handlingsplan for bedre luftkvalitet i Bergen 2007.

Bergen Kommune 2010; Bergen Kommune Luftkvalitet i Bergen 2010, http://www.luftkvalitet.info/Rapporter

Bergen Kommune 2011; Bergen Kommune Luftkvalitet i Bergen 2011, http://www.luftkvalitet.info/Rapporter

Bergen Kommune 2012; Bergen Kommune Luftkvalitet i Bergen 2012, http://www.luftkvalitet.info/Rapporter

Energimyndigheten 2012; Energiläget 2012.

ENOVA 2013; www.enova.no

Future BioTec 2012; http://futurebiotec.bioenergy2020.eu/content/downloads Johansson C, Hansson H-C 2007; PM 10 och sot i Sverige, Institutionen för tillämpad miljövetenskap rapport 165, maj 2007.

Johansson C. et al. 2007; Relationerna mellan halterna av PM 10, PM1 och sot i Sverige, Institutionen för tillämpad miljövetenskap rapport 153, mars 2007.

Kåre Press-Kristensen 2013; Technical University of Denmark - personal communication 2013.

Katja Outinen 2013; Ministry of Environment - personal communication 2013.

KLIF 2010; Klima- og forurensingsdirektoratet; Lokal luftkvalitet. Vurdering av status og behovet for nye tiltak og virkemidler. 29.04.10.

Naturvårdsverket 2009; Effekter av investeringsprogrammen LIP och Klimp, Rapport 5991 augusti 2009.

Naturvårdsverket 2013; Miljöregistret http://klimp.naturvardsverket.se/mir/

Norden and IEA 2013; Nordic Energy Technology Perspective - A Pathway to a Carbon neutral Energy Future.

Nordic Swan 2007; Nordic Ecolabelling of Solid biofuel boilers, ver 2.2 September 2007.

Nordic Swan 2010; Nordic Ecolabelling of Stoves, ver 3.2 October 2010 Notat 12 juni 2013.

NS 3058; Norsk standard 3058, Lukkete ildsteder Røjkutsilpp, juni 1994.

Nussbaumer 2008; Thomas Nussbaumer, Holzenergie-symposium 12/9 2008 Zürich.

Oslo Kommune 2010 mfl; Statens Vegvesen, Oslo kommune, Bærum. Kommune Tiltaksutredning for luftkvalitet i Oslo og Bærum kommune.

Oslo Kommune 2010; Oslo Kommune Bymiljøetaten Årsrapport 2010 Luftkvaliteten i Oslo.

Oslo Kommune 2011; Oslo Kommune Bymiljøetaten Årsrapport 2011, Luftkvaliteten i Oslo. 
Oslo Kommune Enoketaten 2013; www.enoketaten.oslo.kommune.no

Outi Kaarina Väkevä 2013; City of Helsinki - personal communication 2013.

Socialstyrelsen 2009; Miljöhälsorapport 2009.

SSB 2013; Statistisk Sentralbyrå http://www.ssb.no Energiforbruk i husholdninger og fritidshus. 1990-2012.

SSB 2013; Statistisk Sentralbyrå, Norge, Nye vodovener ga 70 tonn mindre støv i Oslo.

STTV 2008; Social och hälsovårdens produkttillsynscentral, Sanitära anvisningar för småskalig förbränning av trä, 12.9.2008.

Trondheim Kommune 2006; Etterbrennerforsøket 2006/2006 Trondheim Kommune Faktaark nr 9 september 2006.

UNECE 2012; http://www.unece.org/env/lrtap/multi_h1.html

UNEP and WMO 2011; Integrated Assessment of Black Carbon and Tropospheric Ozone.

US-EPA 2012; Report to Congress on Black Carbon. 


\section{Acknowledgements}

We are grateful to have received data, reports and being able to conduct several interesting discussions with many authorities, organisations and manufactures of stoves and boiler in the Nordic Countries. Without that support, it had not been possible to produce the report. 



\section{Sammanfattning}

Svart sot (Black Carbon) har sedan länge varit känd som en luftförorening med negativa hälsoeffekter. Det är först under senare år som forskarna har blivit varse sotets förmåga att accelerera klimatförändringarna på kort sikt. Black Carbon ${ }^{8}$ (BC), som är en del av i luften förekommande partiklar PM2.5 (Partiklar med storlekar mindre än 2,5 mikrometer), skapas genom ofullständig förbränning av främst biomassa och fossila bränslen. BC värmer luften genom att absorbera solstrålning och genom att minska jordytans albedo (reflektionsförmåga) över is- och snötäckta områden då sotet avlagras på snö och is. Flera vetenskapliga studier har visat att uppvärmningseffekten är särskilt stor över Arktis där sot, som faller ner på snö och is, tidigarelägger starten för avsmältningen under våren och förstärker avsmältningen under sommaren. När land- och havsområden i Arktis befrias från is och snö värms havsytan och landytan ytterligare vilket också förstärker uppvärmningen.

Då sot bara har en uppehållstid $i$ atmosfären på ett par veckor så skulle minskningar av utsläppen av $\mathrm{BC}$ fă snabbt genomslag i Arktisk under de kommande decennierna genom att minska takten i den globala och den Arktiska uppvärmningen liksom ge betydande positiva hälsoeffekter. De Nordiska länderna, Kanada, och USA bidrar med en stor del av de utsläpp av BC som når Arktis. Utsläppsminskningar i dessa länder skulle ha den största effekten på utvecklingen i Arktis. I de Nordiska länderna är utsläpp från vedeldning den största källan till $\mathrm{BC}$ som når Arktis.

Denna rapport går igenom lagstiftning och andra åtgärder som de Nordiska länderna genomfört för att minska utsläpp från vedeldning av PM2.5 och BC under de senaste decennierna. Rapporten utvärdera effektiviteten av de olika åtgärder som använts i de Nordiska länderna liksom pekar ut de åtgärder som har den största potentialen i att effektivt minska utsläppen av BC och PM2.5.

${ }^{8}$ Black Carbon (BC) definieras som ljusabsorberande kolhaltigt material i denna rapport. BC är inte exakt detsamma som sot även om sot till stor del överlappar definitionen av BC. BC-partiklar är mindre än 1 mikrometer, ofta med storlek kring 0,1 mikrometer. För en mer uttömmande diskussion av BC se Annex I. 
Resultaten kan kortfattat sammanfattas enligt följande:

- Utsläppskrav på utrustning avsedd för vedeldning för uppvärmning av hus under EU:s Ecodesigndirektiv kommer att spela en viktig roll för utvecklingen av bättre spisar, kaminer och små pannor över de kommande decenniet. För att få maximal effekt så måste BC-krav inkluderas explicit i Ecodesigndirektivets tillämpning.

- De Nordiska länderna har de styrmedel som krävs för att reglera utsläpp från vedeldning i enskilda fall såsom dålig luftkvalitet $\mathrm{i}$ omgivningen. Tillämpningen av dessa regelverk varierar dock och de åtgärder som vidtas har ingen eller liten regional effekt.

- Det Nordiska miljömärkningssystemet Svanen har potentialen att driva på utvecklingen i de Nordiska länderna, både vad gäller producenter och konsumenternas medvetande om sotets betydelse. De nordiska länderna måste dock komma överens om ett gemensamt testprotokoll för mätning av sotutsläpp för att göra detta möjligt.

- Ekonomiskt stöd (subventioner) till utfasning av äldre utrustning har haft viss effekt vid några tillfällen lokalt i Norden. Emellertid har man inte studerat vad resultatet skulle blivit i jämförelse med kommuner som inte gett stöd. Det är därför svårt att beräkna eller uppskatta kostnadseffektiviteten hos subventioner av detta slag. Att genomföra nationella stödprogram för utfasning av gamla spisar och pannor skulle bli mycket kostbart och bör främst användas för att stimulera utvecklingen och marknadsanpassningen av innovativa produkter med låga utsläpp.

- Det är tekniskt möjligt att utveckla spisar, kaminer och små pannor med mycket låga utsläpp av BC och PM2.5 och som inte är beroende av användarens förmåga och kunskap om att elda rätt.

- Det är betydande osäkerheter i de emissionsfaktorer de Nordiska länderna använder vilket försvårar jämförelsen av utsläpp i de olika Nordiska länderna. Det gäller även då samma fabrikat och modeller används i de olika länderna. Det är därför viktigt att de testprotokoll som används avspeglar verkliga emissioner i de situationer då utrustningen används. Det är inte fallet idag med exempelvis utsläpp av PM2.5. För BC finns inte än en gemensam BC-standard. Det är speciellt viktigt då det gäller Ecodesigndirektivet.

- Det är möjligt att införa effektiv lagstiftning och utsläppskrav men Nordiskt samarbete är nödvändigt för att utveckla en gemensam långsiktig strategi. Teknisk utveckling bör stimuleras. Producenterna och andra marknadsaktörer har en viktig roll i detta avseende. 
Ytterligare åtgärder kan övervägas om den naturliga omsättningen av äldre ineffektivare utrustning inte är tillräcklig. Det kan ske genom att sätta slutdatum för användning av vissa spisar, kaminer eller pannor som används som huvudsaklig källa till uppvärmning eller genom att använda ekonomiska instrument som differentierade skatter eller avgifter.

Avslutningsvis är det enligt rapporten möjligt att utveckla ny lagstiftning och regelverk som syftar till att minska utsläppen av BC och PM2.5 för att uppnå minskningar i det sot som når Arktis liksom väsentligt förbättra luftkvaliteten och minska den negativa hälsopåverkan från PM2.5 och BC. Det finns goda möjligheter att utveckla detta arbete såväl under Nordiska Ministerrådet som nationellt och i andra internationella forum. Inte minst viktigt är det pågående arbetet inom Ecodesigndirektivet för att ställa krav på utrustning för vedeldning och den Nordiska Svanens pågående arbete med att revidera kraven på nya spisar och pannor för vedeldning avsedda att börja gälla 2015. De Nordiska länderna skulle vinna på att agera snabbt inom dessa processer för att kunna inkludera explicita BC-krav. 



\section{Annex I Formation of Soot - Black Carbon}

This report focus on the emissions of soot (Black Carbon) from wood burning. Problems with emissions from wood burning are however not new. They arise primarily because of a combination of the use inappropriate technology for wood burning and the fact that people do not manage their fires correctly. A number of measures have been taken in the Nordic countries in order to prevent air pollution from wood burning. These measures have not been focused on emissions of black carbon, but rather on local and regional health impacts. However, reducing emissions of Black Carbon will also reduce overall emissions of particulate matter.

\subsection{How soot is formed}

Carbon as a pollutant from burning of bio-fuels can exist in the atmosphere as either organic or black carbon (OC and BC). From a more technical point of view carbonaceous emissions can be defined according to how the particles are measured.

- Black carbon $(B C)$ is measured by its capacity to absorb light.

- Black smoke (BS) is measured by its light reflection on a white filter paper-in fact a measure of total amount of particulate matter.

- Elemental carbon (EC) consists of unburnt material in the form of carbon-carbon bonds.

- Organic carbon $(O C)$ is mixture of unburnt organic carbon chemical compounds. Total organic compounds (TOC) is usually the sum of EC and OC.

Very often emitted BC is transformed by coalescence with other particles and chemical transformations after having left the combustion chamber to more complex particles. Soot or BC is always co-emitted with other compounds but the relative amount of emitted BC can vary significantly depending on burning practices and stove design. 
Wood burning can be divided into three phases (Folke Petersson 1989). In the first phase, when ignition occurs pieces of wood warms up and water vapour escapes. In the second phase the temperature increases and inflammable gases escapes from the wood. And finally a third phase when the inflammable gases has ceased charcoal remains, which takes much longer time to burn, and also requires a higher temperature.

Soot is formed in fuel-rich zones of the flame and can be deposited on cold surfaces in the furnace. Complete combustion happens when there are a sufficiently long residence time for gases and soot formed to be destroyed, a sufficiently high temperature and a sufficient supply of air. It is often necessary that air supplied to the combustion chamber has several points of departure to ensure a complete combustion.

High temperatures and high flue draft increase the risk that hot flue gases quickly leave the chimney leading to a loss of energy efficiency. In a boiler constructed to heat water it is easy to recycle energy in the flue gas into the boiler's convective parts. ${ }^{9}$ A similar effect is obtained in heat-retaining fireplaces on the market. Other stoves have to be designed so that efficiency gains do not occur at the expense of increased emissions of air pollution.

\subsection{Historical data on soot in ambient air}

"Soot" was initially used as a generic term for particulate air pollution from heating, industry and traffic. Blackening of the filter was used as a measure of the total particle concentration in the ambient air as discussed above. This method was developed in the early 1960's to an OECD standard called Black Smoke (BS). Soot measured by this method is not really a measure of the concentration of soot (let al.one black carbon), but merely the particle matter concentration (mass concentration). Since the optical properties of particles vary with the source and age of the particles the relationship between blackening and particle content varies significantly.

\footnotetext{
${ }^{9}$ The parts where the heat from the flue gases is transferred to heating system water.
} 
Since the 1960s, the concentration of classic "soot" in Swedish cities and in the rural environment has fallen sharply, Figure A1.1 and A1.2 (Johansson C, Hansson H-C 2007). It is reasonable to assume that similar trends may be observed in all Nordic countries. Concentration of soot and particulate matter measured as PM 10 does not correlate because the sources are different. A better correlation between soot and $\mathrm{NO}_{2}$ concentrations indicates that the automobiles (primarily diesel) contribute significantly. The correlation between the PM 1, PM 10, organic carbon and soot is substantial in areas with large concentrations of wood stoves and fireplaces (Johansson C. et al. 2007).

Figure A1.1: Concentration of “classical OECD" soot in $\mu \mathrm{g} / \mathrm{m}^{3}$ in Swedish cities 1960-2006

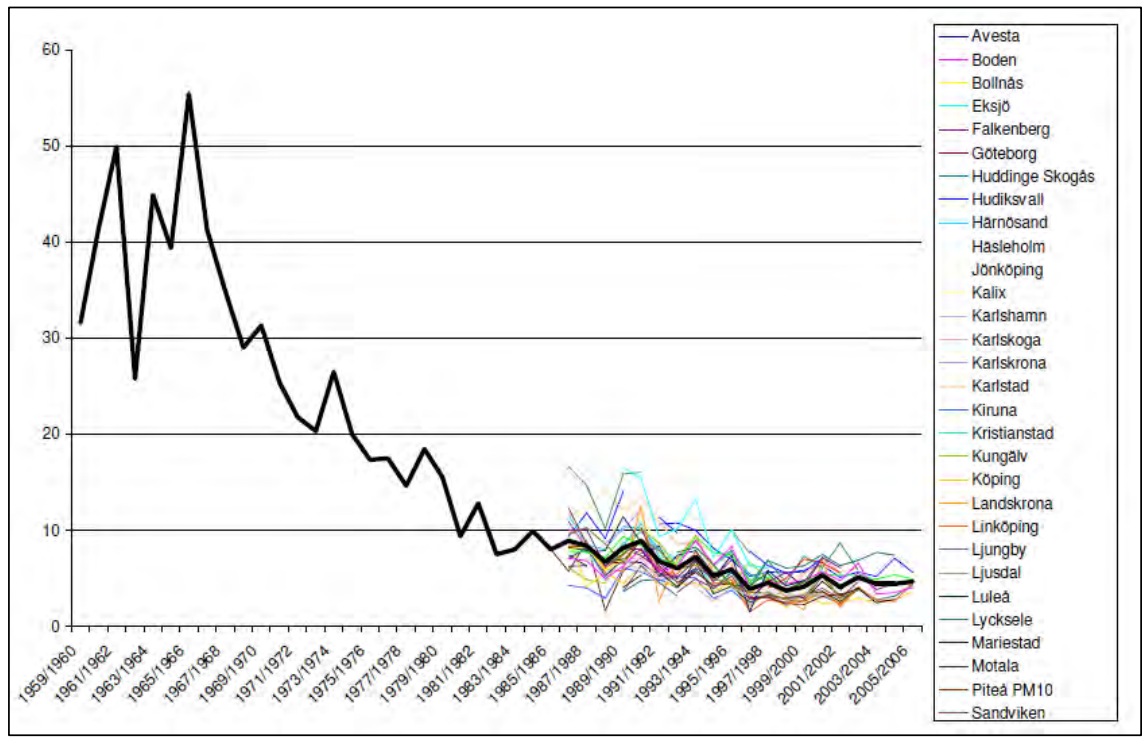


Figure A.1.2: Concentration of "classical OECD" soot in rural areas in Sweden 1978-2005

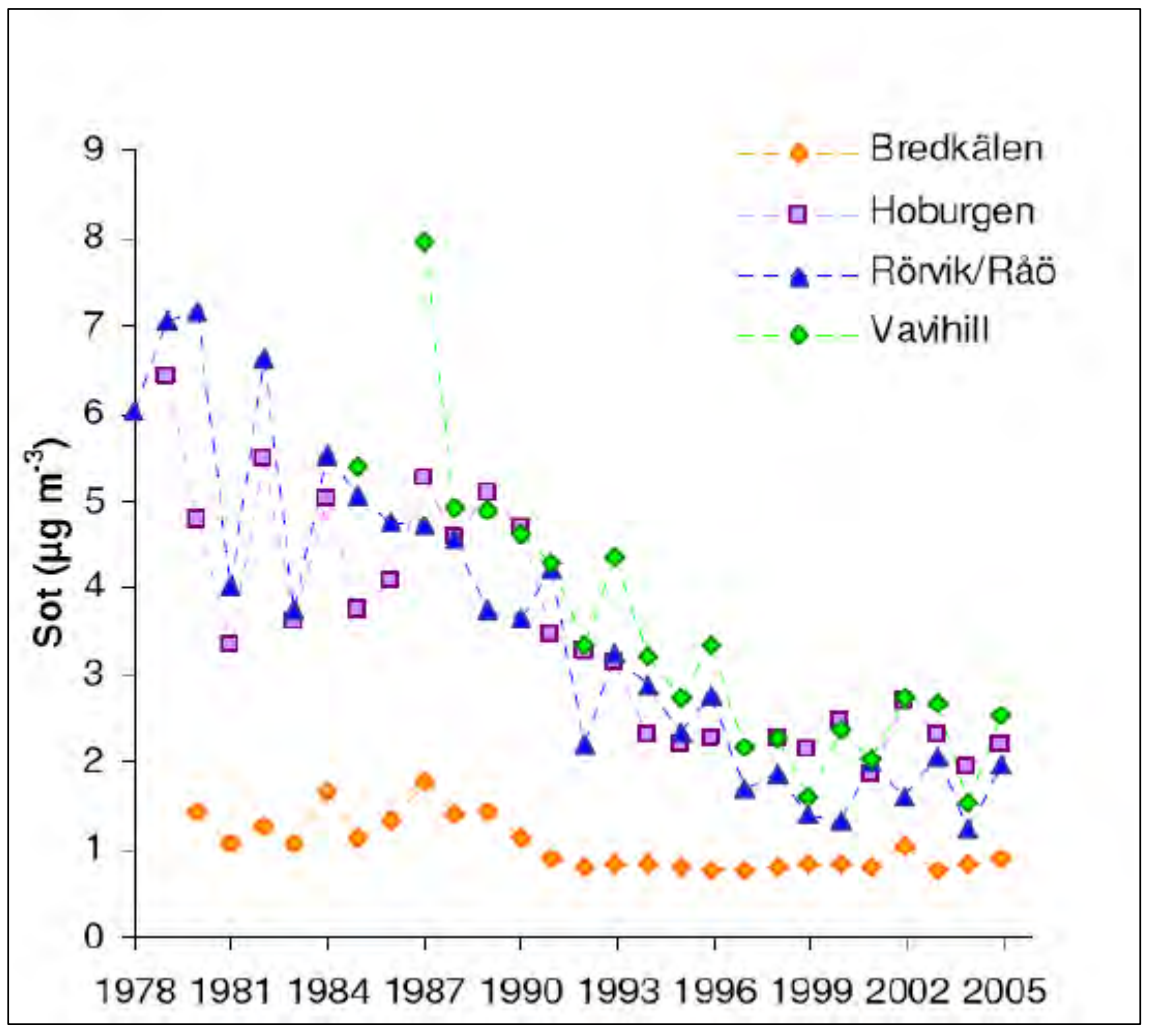




\section{Annex II Wood burning Technologies on the Nordic Market}

The market for domestic heating products shows a great diversity of products across the Nordic countries. Due to various national, cultural, and local conditions, space heating demands have been met in many different ways in the Northern countries. The heating appliance market in general is characterised by its diversity and complexity. However biofuel use plays roughly the same role in meeting the heating demand in the four countries

\subsection{Basic Combustion Technologies}

\subsubsection{Updraft combustion}

This is a conventional technique for the combustion of wood. The fuel is placed in a tray and combustion air is drawn into the combustion chamber, e.g. through a grating at the bottom of boiler. The air passes through the fire-wood box and the flue gases are collected at the top of the combustion compartment. In this construction all logs burn at the same time and the temperature of flue gases tends to be high. This construction has low efficiency. There is also the risk that unburnt gases escapes the combustion chamber into the air. In modern designs convective ${ }^{10}$ facilities have been developed to remedy this weakness in the original design and to use the heat more efficiently. In modern stoves there is often added also a secondary air supply which considerably improves the combustion. This design is sensitive to the amount of wood fed to the furnace. Because of that it is essential not to add more logs to the stove than the manufacturer recommends.

10 The parts where heat from the combustions process transfer to water or air. 


\subsubsection{Down draft combustion}

In this flue gases are taken out just above the grate and the combustion of the logs takes place in the bottom furnace. In modern constructions the final combustion take place in a ceramic part of the furnace. Since only the lower portion of the woodpile burns a more uniform combustion process and lower flue gas temperatures are obtained. All logs are heated and combustible gases are forced through the flame front in the bottom of the compartment. Additional air is supplied through a secondary air supply at the final stages of the combustion for combustion process to be as efficient as possible.

\subsubsection{Reverse combustion}

In reverse combustion the primary air is supplied above the grid in the fireplace and the flue gases are evacuated from the bottom of the combustion chamber. The construction forces the flame front down through the grating into a ceramic part of the chamber where the final combustion occurs. As in the case of down draft combustion it is only the lower part of log pile that burns while the rest of the wood eventually gets charred and migrate down towards the furnace bottom. The construction requires a substantial draught because the flue gases have to be forced down through the grating and these stoves are therefore provided with a chimney exhaust fan. This design provides for high efficiency and low emissions of air pollutants.

It is technically possible to build a stove for under- or reverse combustion, but these designs are not attractive to customers who would like to enjoy a conventional fire.

\subsubsection{Pellets Burners}

Pellets is a uniform fuel and the combustion process can therefore be controlled in a better way than when burning logs. Pellets provide a better and more stable combustion with lower emissions of hydrocarbons and particulates. A pellets stove can supply about $50-80 \%$ of energy consumption for domestic heating, depending on the stove's power and the position in the building. Pellets boilers have almost zero emissions of Black Carbon but can increase in low-load conditions. Also pellets stoves can be designed to give very low emissions of Black Carbon and particulate matter. 


\subsection{Wood burning stoves and boilers on the Nordic Market}

\subsubsection{Kitchen Stoves}

Kitchen stoves could be found almost in every kitchen in the Nordic countries only a few decades ago. Today they have been replaced by separate heating and cooking appliances. However, there are modern cook stove designs that also provide the house with heat by aqueous systems.

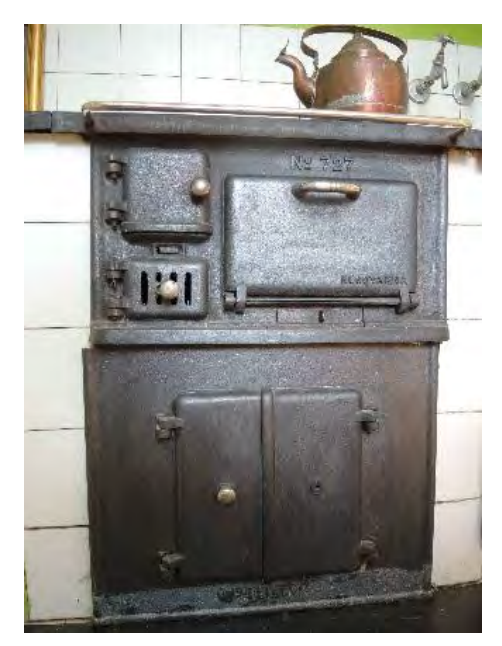

\subsubsection{Stoves}

Originally, simple domestic stoves provided rooms and small houses with all the heat needed. It was common to combine the stove with a cooking place - a surface above the combustion compartment. Today modern stoves are used both for comfort, leisure and to provide heat in the house during periods when additional heating may be needed. Many people also consider the stove as part of the interior decoration. In Sweden they are used primarily in electrically heated homes as a back-up, and to limit the purchase of expensive electricity during the coldest periods of the year. In Denmark, it has also become a complement to district heating or even replaced district heating in many cases.

There are stoves for both logs and pellets. The stoves can be made of sheet metal or cast iron and can be made with or without a ceramic insert. Pellet stoves have a storage compartment for pellets integrated with the stove, enough for a couple of days. Pellet stoves spread heat 
through ventilation systems or water-jacketed models, coupled to an existing radiator system.
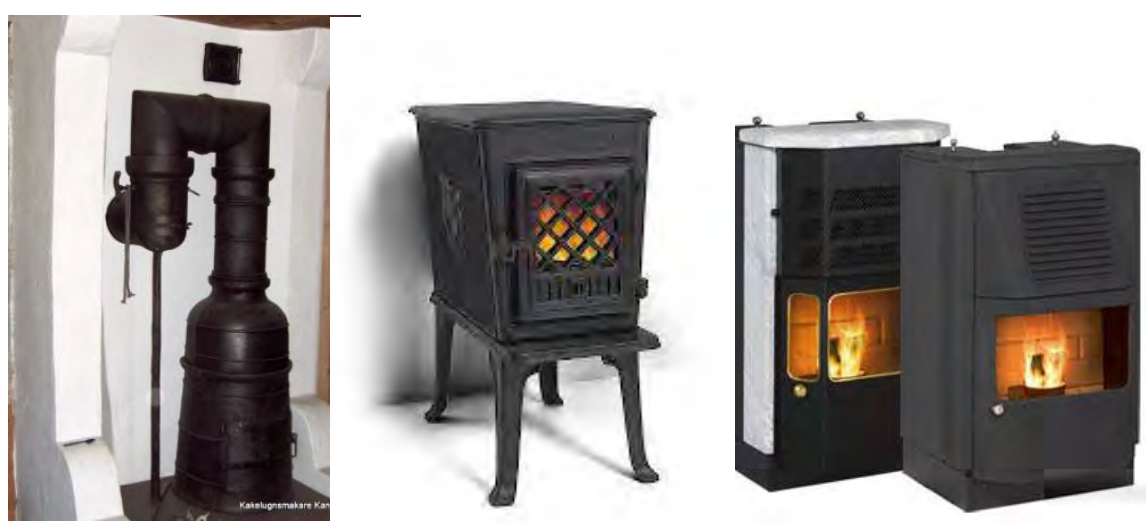

The pictures show from left an old Swedish cast iron stove, a modern Norwegian cast iron stove and modern pellet stoves from Finland.

\subsubsection{Boilers}

Boilers are used for the main supply of heat in a house by providing hot water to be circulated through radiators. It also provides hot water for other domestic activities. There are different types of boilers on the market. During the so-called Energy crisis in the 1970s, so-called combi boilers where developed. They could use fuel oil, wood or electricity as energy carrier. These old boilers have very high emissions when burning wood and are still in use.
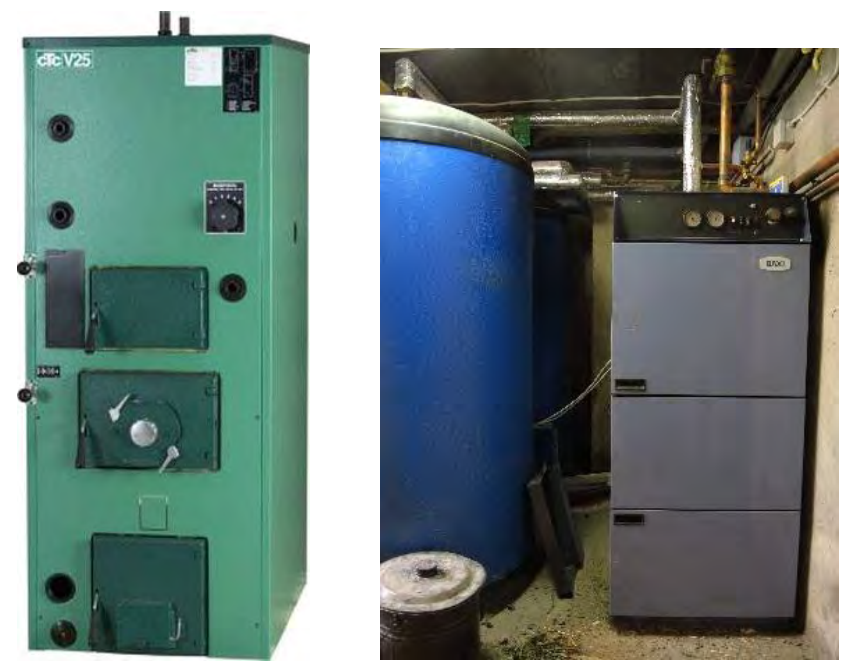

A combi-boiler from Sweden and a modern wood fired boiler from Denmark 
Today both cast iron boilers and boilers with ceramic inserts are manufactured. Some are designed for logs while others are designed to use wood-pellets or wood-chips.

It is desirable that these boilers are used together with an insulated accumulator tank, with a capacity to store hot water for use over periods of time of the order of 24 hours during the cold season. The advantage with such boilers is that they only need to be fired at intervals and then at their maximum power output to keep the water in the accumulator tank at the appropriate temperature. This results in lower emissions of air pollutants by decreasing the number of start-ups of the boiler but also by avoiding closing the air supply to prevent the charcoal from smouldering.

\subsubsection{Masonries}

Another method to store heat is to use a heavy solid construction in which the heat can be stored connected to the fireplace. There are many types of designs. The oldest masonries are the tiled stoves that employ heat-exchange channels that provide additional surface area. These absorb heat from the hot exhaust gases before the gases exit into the chimney. The Finnish soapstone fireplaces or stoves constructed from brick have the same function as a tiled stove, but in a modern design. It is possible that the furnace combines cooking or baking with domestic heating. These designs usually require special support to bear their extreme weight.
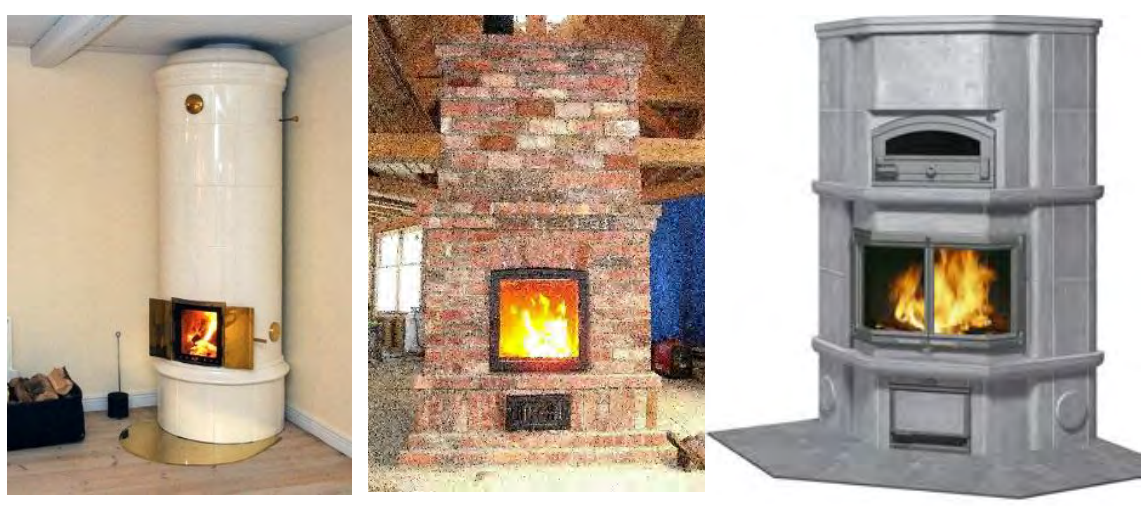

Different kinds of masonries 


\subsubsection{Open fireplace}

The simplest form is an open fireplace is used primarily for relaxing and comfort. The efficiency is low but it can be improved by a fireplace insert, making the open fireplace closed and more efficient - but less attractive. An open fireplace is not sufficiently effective to provide a domestic heating source. Open fireplaces generally emit high amounts of particulate matter and Black Carbon.

\subsubsection{Sauna Stoves}

A special type of fireplace is a stove used to heat the sauna. The stove design can vary but a general feature is that sauna stoves are not used continuously for heating purposes. The firing pattern is more like a cook stove. Another characteristic is that a tray of stones on top of the fireplace is used to raise the humidity in the sauna by throwing water on it. Sauna stoves generate significant Black Carbon emissions primarily in Finland.

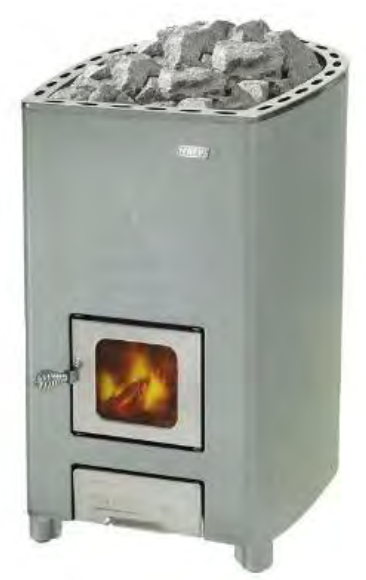

A Finnish sauna stove. 
Nordic Council of Ministers

Ved Stranden 18

DK-1061 Copenhagen K

www.norden.org

\section{Controlling Emissions from Wood Burning}

This report has been produced by the International Cryosphere Climate Initiative (ICCI) under a grant from the Nordic Council of Ministers under its Arctic Cooperation Program, as part of a pilot project to reduce emissions of black carbon reaching the Arctic from residential heating from wood burning in Nordic countries. The report reviews legislation and other measures in the Nordic countries pertinent to the reduction of particulate matter (PM2.5) and Black Carbon (BC) -soot. It then assesses the effectiveness of the different policy instruments used in the Nordic countries as well as points to measures which may be most effective in reducing emissions of Black Carbon and PM2.5 from wood burning. 